Document downloaded from:

http://hdl.handle.net/10251/165300

This paper must be cited as:

Costantino, A.; Fabrizio, E.; Villagrá, A.; Estellés, F.; Calvet, S. (2020). The reduction of gas concentrations in broiler houses through ventilation: Assessment of the thermal and electrical energy consumption. Biosystems Engineering. 199:135-148.

https://doi.org/10.1016/j.biosystemseng.2020.01.002

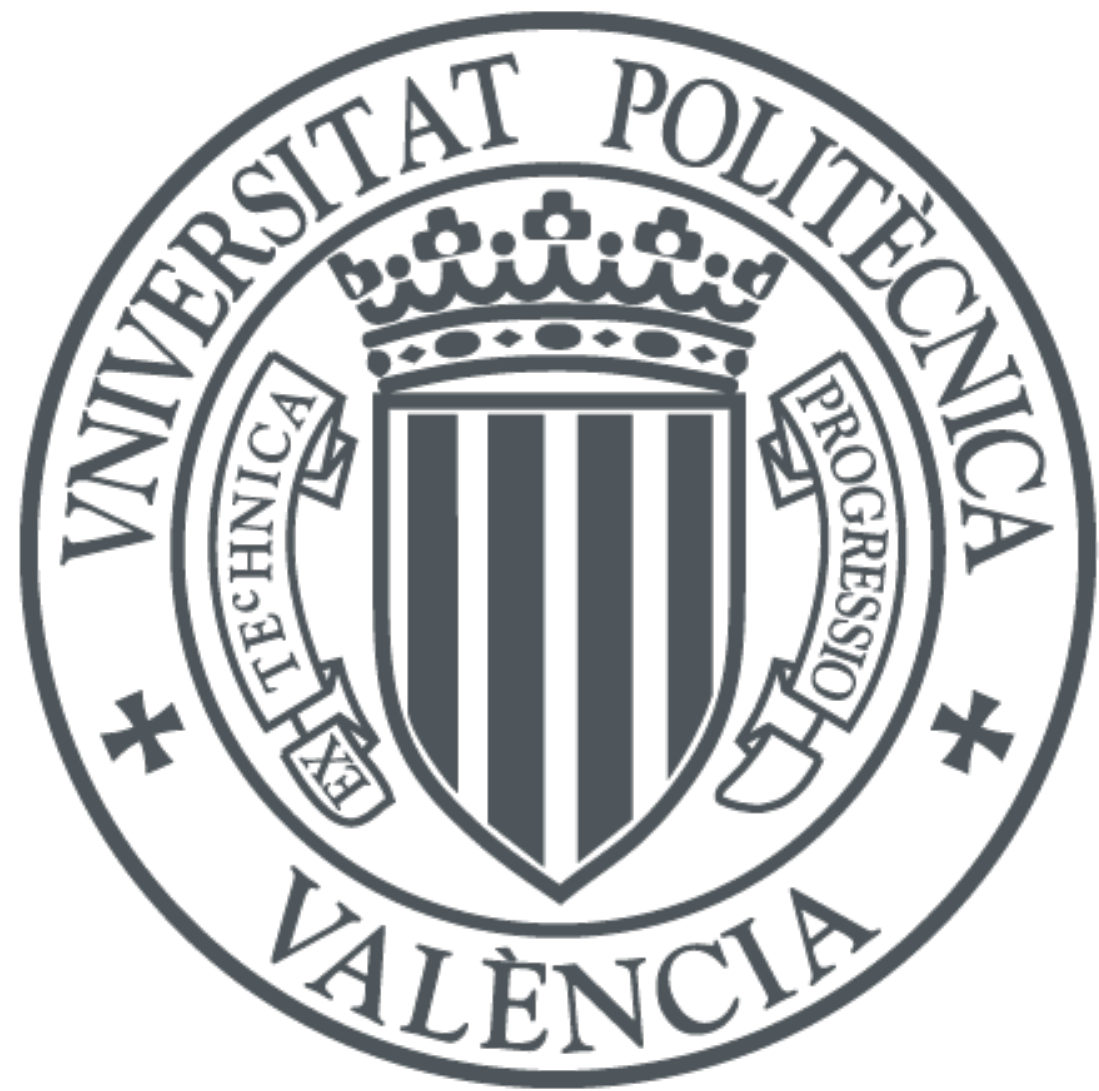

The final publication is available at

https://doi.org/10.1016/j.biosystemseng.2020.01.002

Copyright Elsevier

Additional Information 


\title{
The reduction of gas concentrations in broiler houses through ventilation: assessment of the thermal and electrical energy consumption
}

\author{
Andrea Costantino ${ }^{1,2 *}$, Enrico Fabrizio ${ }^{2}$, Arantxa Villagrá ${ }^{3}$, Fernando Estellés ${ }^{1}$, Salvador \\ Calvet $^{1}$ \\ ${ }^{I}$ Institute of Animal Science and Technology, Universitat Politècnica de València, Camino de Vera s/n, 46022, \\ València, Spain \\ ${ }^{2}$ DENERG, Politecnico di Torino, TEBE Research Group, Corso Duca degli Abruzzi 24, 10129 Torino, Italy \\ ${ }^{3}$ Centro de Tecnología Animal, Instituto Valenciano de Investigaciones Agrarias, Polígono de la Esperanza 100, \\ 12400, Segorbe, Castellón, Spain \\ *Corresponding author. Tel: +390110904552 \\ E-mail address: andrea.costantino@polito.it
}

\section{Abstract}

Ammonia and carbon dioxide are the most relevant among the harmful gases present in broiler houses and their effects on animal health depend on concentration and exposure time. Inside these houses, increasing ventilation is the most common strategy adopted to control the concentration of these gases. This strategy is effective but increases the electrical energy consumption (for fan operation) and the thermal energy consumption (for inlet air heating). In this work, the variations of the energy consumptions due to the increase of ventilation for maintaining ammonia and carbon dioxide concentrations below established thresholds were evaluated. To carry out this analysis, various parameters (e.g. indoor air temperature and gas concentrations) of a broiler house located in the Mediterranean area were monitored during a production cycle in the cool (winter) season in which outdoor air temperature varied between 2 and $25{ }^{\circ} \mathrm{C}$. The assessment of the increase of the energy consumption for climate control was carried out using the Specific Fan Performance and a customized building energy simulation model.

The analysis showed that during the monitored period, the established thresholds of gas concentrations were exceeded approximately $60 \%$ of time. To maintain the desired gas concentration, the ventilation flow rate should be increased by $9 \%$. This variation in the ventilation flow rate entailed a rise in the energy consumption by about $10 \%$ for electrical energy and by about $14 \%$ for thermal energy. Maintaining the gas concentration below the established thresholds entails an extra cost of around $0.02 €$ per harvested broiler. 
33 Keywords: broiler production; climate control; animal breeding; energy assessment; ammonia emission; animal welfare

35

$36 \quad$ Nomenclature

Air

air (subscript)

38

39

$40 \quad b_{1}$

broiler (subscript)

coefficient for $S F P$ calculation

$\left[\mathrm{m}^{3} \mathrm{Wh}^{-1}\right]$

coefficient for $S F P$ calculation

$\left[\mathrm{m}^{3} \mathrm{Wh}^{-1} \mathrm{~Pa}^{-1}\right]$

$41 \quad b_{2}$

coefficient for SFP calculation

$\left[\mathrm{m}^{3} \mathrm{Wh}^{-1} \mathrm{~Pa}^{-2}\right]$

$42 \mathrm{C}$

cooling (subscript)

$43 \mathrm{c}$

central (subscript)

$44 \quad C$

gas mass concentration

[ppm]

$45 \quad \bar{C}$

gas mass concentration (mean value)

[ppm]

$46 \quad E$

energy consumption with actual ventilation

[kWh]

$47 \quad E^{\prime}$

energy consumption with increased ventilation

$[\mathrm{kWh}]$

$48 \mathrm{e}$

exhaust (subscript)

49 el

electrical energy (subscript)

$50 f$

primary energy conversion factor

$\left[\mathrm{kWh}_{\mathrm{p}} \mathrm{kWh}^{-1}\right]$

51 fan

fan (subscript)

$52 \mathrm{H}$

heating (subscript)

53 hor

horizontal (subscript)

$54 \quad I$

solar irradiance

[W m $\left.\mathrm{W}^{-2}\right]$

55 i

indoor (subscript)

56 IAQ

Indoor Air Quality

$57 \mathrm{j}$

generic hourly time step (subscript)

$58 \quad 1$

large fans (subscript)

$59 \lim$

gas concentration limit (subscript)

$60 m$

molecular mass

$\left[\mathrm{kg} \mathrm{mol}^{-1}\right]$

610

outdoor (subscript)

$62 \mathrm{p}$

primary energy (subscript)

$63 \dot{q}$

gas emission

$\left[\mathrm{mg} \mathrm{h}^{-1}\right]$

$64 \quad R H$

air relative humidity

[\%]

$65 \mathrm{~s}$

small fans (subscript) 


\begin{tabular}{|c|c|c|c|}
\hline 66 & set & set point (subscript) & \\
\hline 67 & $S F P$ & specific fan performance & {$\left[\mathrm{m}^{3} \mathrm{Wh}^{-1}\right]$} \\
\hline 68 & th & thermal energy (subscript) & \\
\hline 69 & tot & total (subscript) & \\
\hline 70 & $U$-value & steady-state thermal transmittance & {$\left[\mathrm{W} \mathrm{m} \mathrm{m}^{-2} \mathrm{~K}\right]$} \\
\hline 71 & $V_{\mathrm{mol}}$ & molar volume & {$\left[\mathrm{m}^{3} \mathrm{~mol}^{-1}\right]$} \\
\hline 72 & $\dot{V}$ & actual ventilation air flow rate & {$\left[\mathrm{m}^{3} \mathrm{~h}^{-1}\right]$} \\
\hline 73 & $\dot{V}^{\prime}$ & increased ventilation air flow rate & {$\left[\mathrm{m}^{3} \mathrm{~h}^{-1}\right]$} \\
\hline 74 & $w$ & live weight & {$[\mathrm{kg}]$} \\
\hline 75 & $\mathrm{x}$ & generic gas (subscript) & \\
\hline 76 & $\Delta p$ & static pressure difference & {$[\mathrm{Pa}]$} \\
\hline 77 & $\Delta \dot{V}^{\prime}$ & difference between actual and increase ventilation & {$\left[\mathrm{m}^{3} \mathrm{~h}^{-1}\right]$} \\
\hline 78 & $\eta$ & conversion efficiency & {$[-]$} \\
\hline 79 & $\theta$ & temperature & {$\left[{ }^{\circ} \mathrm{C}\right]$} \\
\hline 80 & $\theta^{\prime}$ & temperature (considering the increased ventilation) & {$\left[{ }^{\circ} \mathrm{C}\right]$} \\
\hline 81 & $\kappa$ & areal heat capacity & {$\left[\mathrm{kJ} \mathrm{m}^{-2} \mathrm{~K}^{-1}\right]$} \\
\hline 82 & $\Phi$ & heat load & {$[\mathrm{kW}]$} \\
\hline 83 & $\Phi^{\prime}$ & heat load considering the increased ventilation & {$[\mathrm{kW}]$} \\
\hline 84 & $\omega$ & percentage of activation time of the fans & {$[\%]$} \\
\hline
\end{tabular}

\section{Introduction}

The accumulation of aerial pollutants inside animal farms impairs animal health and welfare and reduces farm efficiency and productivity. The most relevant among the harmful gases in broiler houses are ammonia $\left(\mathrm{NH}_{3}\right)$ and carbon dioxide $\left(\mathrm{CO}_{2}\right)$. Their effects on broilers depend on their concentration as well as on the exposure duration.

Atmospheric $\mathrm{NH}_{3}$ in poultry facilities has been recognized as a significant environmental problem, as well as a detriment to poultry health, performance and welfare (Kristensen, Burgess, Demmers, Wathes, 2000). It causes ocular damages when broilers are exposed to 25 and $50 \mathrm{ppm}\left(1 \mathrm{ppm}\right.$ of $\mathrm{NH}_{3}$ is $0.7 \mathrm{mg} \mathrm{m}^{-3}$ at atmospheric pressure and $25{ }^{\circ} \mathrm{C}$ of gas temperature) for 14 days (Olanrewaju et al., 2007), and keratoconjunctivitis and other eye disorders when exposed to 60 ppm (Valentine, 1964; Beker, Vanhooser, Swartzlander, Teeter, 2004). Ammonia is also absorbed by the distal airway mucus, which enhances mucosal inflammation and bacterial contamination of the lungs (Gustin, Urbain, Prouvost, Ansay, 
1994). Moreover, exposure to $\mathrm{NH}_{3}$ also promotes the development of infections (Kristensen and Wathes, 2000) and enhances susceptibility to respiratory diseases (Beker et al., 2004). Breast blisters have also been found in environments of 25 and $50 \mathrm{ppm}$ of $\mathrm{NH}_{3}$ (Quarles and Kling, 1974). More recently, it was found that broilers exposed to $25 \mathrm{ppm}^{\circ} \mathrm{NH}_{3}$ had a higher expression of genes potentially inhibiting growth and development of breast muscle, compared to broilers exposed to 3 ppm (Yi et al., 2016).

High $\mathrm{CO}_{2}$ concentrations have negative consequences on broilers due to both the direct effect of this gas and the decrease in the oxygen concentration (McGovern, Feddes, Zuidhof, Hanson, Robinson, 2001). According to Gerritzen, Lambooij, Reimert, Stegeman, and Spruijt, (2007), broilers start to notice instantaneously the presence of $\mathrm{CO}_{2}$ at 24,000 ppm (1 ppm of $\mathrm{CO}_{2}$ is $1.8 \mathrm{mg} \mathrm{m}^{-3}$ at atmospheric pressure and $25^{\circ} \mathrm{C}$ of gas temperature). Higher concentration values in the breathing air may cause gasp $(92,000 \mathrm{ppm})$ and convulsions $(300,000 \mathrm{ppm})$. Lower concentrations of $\mathrm{CO}_{2}$ could affect broiler health when they are in contemporaneity with high exposure times. For example, when broilers are exposed to $\mathrm{CO}_{2}$ concentrations between 3,000 and 6,000 ppm for 14 days, body weight is depressed and late mortality increases (Olanrewaju et al., 2008).

According to these findings, it is recommended to maintain $\mathrm{NH}_{3}$ and $\mathrm{CO}_{2}$ concentrations below certain limits. In some regions, welfare regulations have also established concentration limits. European Council Directive 2007/43/EC (European Council, 2007) sets the minimum requirements for the protection of broilers kept for meat production and, among these rules, it establishes the maximum density for reared broilers at $33 \mathrm{~kg} \mathrm{~m}^{-2}$. However, the maximum rearing density can be increased up to $42 \mathrm{~kg} \mathrm{~m}^{-2}$ when specific environmental control requirements are accomplished. Among these requirements, $\mathrm{NH}_{3}$ concentration must be kept below $20 \mathrm{ppm}$ and $\mathrm{CO}_{2}$ concentration below 3,000 ppm at the level of the broilers' heads. It has been reported that most commercial farms across Europe rear broilers at densities higher than $33 \mathrm{~kg} \mathrm{~m}^{-2}$ (Verspecht, Vanhonacker, Verbeke, Zoons, Van Huylenbroeck, 2011). However, gas concentrations exceeding the limits established by the 2007/43/EC Directive have also been reported in commercial poultry houses for both $\mathrm{NH}_{3}$ (Groot Koerkamp et al., 1998) and $\mathrm{CO}_{2}$ (Knížatová et al., 2010).

Ventilation design and operation is critical to maintain gas concentrations below harmful levels. Increasing the ventilation rate reduces gas concentration by dilution, which is simple in terms of management and could be easily carried out by the automatic climate control systems installed in farms. However, increasing the ventilation rates increases energy consumption 
and, consequently, may entail an extra cost for the farmer. This is due to the extra electrical energy needed for operating the fans and to the extra supplemental heating load needed to maintain the indoor air set point temperature, particularly in cold conditions (Costantino \& Fabrizio, 2020). Furthermore, climate control systems are mostly programmed to control only air temperature and relative humidity inside livestock houses (Zhang and Barber, 1995) and therefore installation of specific sensors is required.

Rearing broilers involves a high energy consumption compared with other livestock farms. According to Costantino, Fabrizio, Biglia, Cornale and Battaglini (2016), climate control in broiler farms uses between 85 and $135 \mathrm{kWh}_{\mathrm{th}} \mathrm{m}^{-2} \mathrm{a}^{-1}(1 \mathrm{kWh}=3.6 \mathrm{MJ})$ of thermal energy and between 4 and $11 \mathrm{kWh}_{\mathrm{el}} \mathrm{m}^{-2} \mathrm{a}^{-1}$ of electrical energy. These values represent $96 \%$ of the total thermal energy and $75 \%$ of the total electrical energy consumptions of the house. These high energy consumptions reflect also in the running costs of the farm: in the European context, the energy share represents $20 \%$ of the total production cost of a broiler (excluding feedstuff) and can be estimated between 0.04 and $0.09 €$ broiler $^{-1}$ (Oviedo-Rondón, 2010). Finally, considering that the meat production is estimated to increase by $70 \%$ in 2050 (FAO, 2011), the use of energy is also expected to increase in the primary sector (Thornton, 2010). For these reasons, quantifying potential impacts of increasing ventilation on energy consumption is of a foremost importance.

The objective of this work is to explore how energy consumption is affected by the increase of the ventilation rates in a commercial broiler house to fulfil the recommended thresholds of gas concentrations. This kind of analysis is not present in literature and may be useful for both engineers and farmers.

To carry out this work, $\mathrm{NH}_{3}$ and $\mathrm{CO}_{2}$ concentrations and their thresholds established by the European regulation (20 and 3,000 ppm in mass, respectively) are considered. For the analysis, a mechanically ventilated broiler house located in a Mediterranean area was selected as a case study and it was monitored during a production cycle carried out in cool (winter) season. The monitoring campaign provided the gas concentrations and the needed inputs for estimating the thermal and electrical energy consumption.

\section{Materials and methods}

\subsection{Overview on the experimental and simulation activity}

The experimental activity concerned the monitoring of indoor and outdoor gas concentrations $\left(\mathrm{CO}_{2}\right.$ and $\left.\mathrm{NH}_{3}\right)$, indoor and outdoor environmental conditions, static pressure difference 
between inside and outside the broiler house and the working time of the fans. The monitoring campaign concerned 40 days out of 47 of a production cycle carried out during the cool season (December and January). The first week of the production cycle was not monitored. When $\mathrm{NH}_{3}$ and $\mathrm{CO}_{2}$ concentrations exceeded 20 and 3,000 ppm (respectively), the theoretical extra ventilation flow rate needed to maintain the $\mathrm{NH}_{3}$ and $\mathrm{CO}_{2}$ concentrations below the established limits was estimated through a gas mass balance.

The variation of the energy consumption was assessed considering the electrical energy consumption for the operation of the fans and the thermal energy consumption for heating the enclosure. The electrical energy consumption was calculated through the Specific Fan Performance (SFP) obtained through regressions on the technical datasheets of the fans. The thermal energy consumption was estimated using the dynamic energy simulation model for broiler houses developed by Costantino, Fabrizio, Ghiggini, and Bariani (2018).

\subsection{Case study description}

\subsubsection{Housing and reared broilers}

The experiment was carried out in a commercial mechanically ventilated broiler house located in Vila-real (Castellón province, eastern Spain), a geographical location in a Mediterranean climate. The province of Castellón is classified as an hot-humid climate zone (ASHRAE, 2016) characterized by a mild climate with no dry season and hot summer. The heating degree days are $1579{ }^{\circ} \mathrm{C} \mathrm{d}$ calculated considering $20^{\circ} \mathrm{C}$ as base temperature and the entire year as calculation period, in compliance with EN ISO 15927-6 (European Committee for Standardisation, 2007).

The selected case study can be considered representative of the commercial broiler farms of that region. The building floor area is $1,430 \mathrm{~m}^{2}$ (110 $\mathrm{m}$ length and $13 \mathrm{~m}$ width). The building has a gable roof and its height is $2.5 \mathrm{~m}$ at the eave level, and $4.5 \mathrm{~m}$ at the ridge level. The building net volume is approximately $5,000 \mathrm{~m}^{3}$.

The perimetral walls are made of concrete hollow blocks (150 mm of thickness) and cement plaster (20 mm of thickness). Part of these walls is insulated through polyurethane sandwich panels (30 $\mathrm{mm}$ of thickness). The roof is made of corrugated fibre-cement sheets with fiberglass insulation panels (30 mm of thickness) and polyurethane foam (20 mm of thickness) that was applied on the inner face. The floor is a lightweight reinforced concrete screed (100 mm of thickness) in direct contact with the ground. A layer of rice hulls of about $100 \mathrm{~mm}$ is used as bedding material and the litter is removed at the end of each production 
cycle. To perform the energy simulations, an additional $1.5 \mathrm{~m}$ of soil layer is added to the previously described floor layers with the aim of considering the effect of the ground on the building thermal behaviour. The heat flow via the ground was calculated using as thermodynamic driving force the difference between the indoor air temperature $\left(\theta_{\mathrm{air}, \mathrm{i}}\right)$ and the outdoor air temperature $\left(\theta_{\text {air,o }}\right)$.

The thermal transmittance ( $U$-value) and the internal areal heat capacity $\left(\kappa_{\mathrm{i}}\right)$ of the broiler house envelope were calculated in compliance with ISO 6946 (2017a) and ISO 13786 (2017b) standards. The calculated values (reported in Table 1) are the inputs for the energy simulation model that was used to estimate the thermal energy consumption of the analysed broiler house.

Table 1 - Thermal transmittance ( $U$-value) and internal areal heat capacity $\left(\kappa_{\mathrm{i}}\right)$ of the considered building elements.

\begin{tabular}{ccc}
\hline Building element & $\begin{array}{c}U \text {-value } \\
{\left[\mathrm{W} \mathrm{m}^{-2} \mathrm{~K}^{-1}\right]}\end{array}$ & $\begin{array}{c}\kappa_{\mathrm{i}} \\
{\left[\mathrm{kJ} \mathrm{m}^{-2} \mathrm{~K}^{-1}\right]}\end{array}$ \\
\hline Not insulated walls & 2.40 & 56.3 \\
Insulated walls & 0.67 & 13.3 \\
Roof & 0.42 & 3.4 \\
Floor & 0.44 & 16.3 \\
\hline
\end{tabular}

The production cycle started on December $15^{\text {th }}$ with 12,000 male and 12,000 female broiler chicks and ended on January $31^{\text {st }}$ ( 7 weeks cycle). The monitoring campaign started on the $7^{\text {th }}$ day of the production cycle (December $22^{\text {nd }}$ ) and lasted 967 hours (around 40 days) until the end of the production cycle. On January $24^{\text {th }}, 15 \%$ of the 42 -day-old broilers were harvested from the building with an average weight of $2.33 \mathrm{~kg} \mathrm{broiler}^{-1}$. Total mortality during the growing period was $3.28 \%$. The final production was 23,212 broilers with a total final live weight of $62,534 \mathrm{~kg}$ (2.69 $\mathrm{kg}$ broiler $^{-1}$ for 48-day-old broilers), with a feedstuff consumption of $114,000 \mathrm{~kg}$ and a feed conversion rate of 1.82 . Rearing density at the end of the cycle was $37.05 \mathrm{~kg} \mathrm{~m}^{-2}$, a value higher than the threshold of $33 \mathrm{~kg} \mathrm{~m}^{-2}$ established by the European Council Directive 2007/43/EC (European Council, 2007), therefore specific environmental control requirements should be accomplished.

\subsubsection{Climate control system}

The broiler house is mechanically ventilated using a cross ventilation configuration. Air inlets are placed on one of the larger walls and they are automatically controlled for maintaining a constant pressure difference between inside and outside the building $(\Delta p)$ during the same 
day. On the opposite wall there are 16 lateral exhaust fans that deal with both Indoor Air Quality (IAQ) control and cooling ventilation. The 16 fans are of two different models: nine of them are larger than the other ones. The larger fans have a maximum electrical power of $0.75 \mathrm{~kW}$ and in free air delivery conditions $(\Delta p=0 \mathrm{~Pa})$ the maximum declared airflow is around $35,000 \mathrm{~m}^{3} \mathrm{~h}^{-1}$. The remaining seven fans are smaller, have a maximum electrical power of $0.59 \mathrm{~kW}$ and the maximum declared airflow in free air delivery conditions is roughly $12,750 \mathrm{~m}^{3} \mathrm{~h}^{-1}$. Both fan models are three-phase and fixed propeller speed fans, therefore the air flow and the $S F P$ vary according to $\Delta p$ only on a single curve.

In the broiler house, a commercial automatic control system measures the value of $\theta_{\text {air,i }}$ (through a probe inside the house) and maintains it within the deadband $\left(2{ }^{\circ} \mathrm{C}\right.$ of range) between the heating set point temperature $\left(\theta_{\mathrm{set}, \mathrm{H}}\right)$ and the cooling set point temperature $\left(\theta_{\text {set }, \mathrm{C}}\right)$. When a supplemental heating load is needed to maintain $\theta_{\text {air,i }}$ above $\theta_{\text {set }, \mathrm{H}}$, the farm automatic control system activates two propane air heaters of $85 \mathrm{~kW}$. Both the air heaters are placed inside the building, therefore a conversion efficiency $\left(\eta_{H}\right)$ of $100 \%$ is considered. Since the air heaters emit the exhaust fumes directly inside the enclosure, they contribute to the increase the $\mathrm{CO}_{2}$ concentration.

When cooling is needed to maintain $\theta_{\text {air,i }}$ below $\theta_{\text {set,C, }}$, cooling ventilation and evaporative pads are activated. Climate control system provides also a minimum ventilation flow rate (based only on the animal density) to control the IAQ.

The ventilation is managed through the activation of the 16 fans according to two different activation cycles. When low ventilation flow rates are needed (usually for IAQ control), the activation cycle lasts $15 \mathrm{~s}$. When higher ventilation flow rates are needed (usually for cooling ventilation), the control system manages the fans with activation cycles of $100 \mathrm{~s}$. For ventilation flow rates below $75,000 \mathrm{~m}^{3} \mathrm{~h}^{-1}$, only the small fans are activated.

\subsection{Monitoring system}

The indoor air temperature $\theta_{\mathrm{air}, \mathrm{i}}$ and the indoor air relative humidity $\left(R H_{\mathrm{i}}\right)$ were monitored using four sensors embedded in portable data loggers that were set with an acquisition time step of 30 minutes (HOBO U12, Onset Computer Corp., Pocasset, Mass.).

The outdoor weather conditions of $\theta_{\text {air,o }}$ and relative humidity $\left(R H_{\mathrm{o}}\right)$ were monitored using a weather station that was set with an acquisition time step of 10 minutes (HOBO, Onset Computer Corp., Pocasset, Mass). The daily value of $\Delta p$ was obtained by the logged data in 
254 the farm automatic climate control system that manages the window openings to maintain a 255 constant $\Delta p$ on a daily basis.

256 The total horizontal solar irradiance ( $\left.I_{\text {tot,hor }}\right)$ was obtained with a 30 minutes time step 257 through a third-party weather station. The beam and diffuse components of the solar radiation 258 were obtained using the model of Reindl, Beckman, and Duffie (1990).

259 The percentage of activation time of the nine large fans $\left(\omega_{l}\right)$ and the seven small ones $\left(\omega_{s}\right)$, were monitored with a time step of $90 \mathrm{~s}$ as described in Calvet, Cambra-López, Blanes-Vidal, 261 Estellés, and Torres (2010). The measurement of gas concentration regarded $\mathrm{NH}_{3}$ and $\mathrm{CO}_{2}$. A 262 photoacoustic multi gas monitor equipped with a gas multiplexer was adopted in this work. 263 This instrument enabled sequential measurements in 8 different points in a 2-hour time step 264 (15 minutes are needed to complete each measurement). Four sampling points were placed 265 next to the fans of the building at $1.2 \mathrm{~m}$ of height to determine the exhaust concentrations of 266 the gas $x\left(C_{\mathrm{e}, \mathrm{x}}\right)$, and two were placed at the air inlet openings for the characterization of gas concentration of the outside air $\left(C_{0, \mathrm{x}}\right)$. The remaining two measurement points were placed in the centre of the building at $1.2 \mathrm{~m}$ height to obtain further data on the distribution of gas concentrations $\left(C_{\mathrm{c}, \mathrm{x}}\right)$ within the enclosure. The summary of the measured parameters is presented in Table 2, while the locations of the sensors inside the analysed broiler house is 271 shown in Fig. 1.

272 Every week, 50 broilers ( $0.02 \%$ of the flock) were weighed for monitoring the trend of their 273 live weight $\left(w_{\mathrm{b}}\right)$ during the experiment.

Table 2 - Detail of the monitored parameters.

\begin{tabular}{ccccc}
\hline Monitored parameter & Symbol & $\begin{array}{c}\text { Unit of } \\
\text { measurement }\end{array}$ & $\begin{array}{c}\text { Number of } \\
\text { simultaneous } \\
\text { measurements }\end{array}$ & $\begin{array}{c}\text { Acquisition } \\
\text { time step }\end{array}$ \\
\hline Activation time of large fans & $\omega_{\mathrm{l}}$ & $\%$ & 1 & 90 seconds \\
Activation time of small fans & $\omega_{\mathrm{s}}$ & $\%$ & 1 & 90 seconds \\
Outdoor air temperature & $\theta_{\mathrm{air}, \mathrm{o}}$ & ${ }^{\circ} \mathrm{C}$ & 1 & 10 minutes \\
Outdoor relative humidity & $R H_{\mathrm{o}}$ & $\%$ & 1 & 10 minutes \\
Indoor air temperature & $\theta_{\mathrm{air}, \mathrm{i}}$ & ${ }^{\circ} \mathrm{C}$ & 4 & 30 minutes \\
Indoor relative humidity & $R H_{\mathrm{i}}$ & $\%$ & 4 & 30 minutes \\
Total horizontal solar irradiance & $I_{\mathrm{tot}, \mathrm{hor}}$ & $\mathrm{W} \mathrm{m}{ }^{-2}$ & 1 & 30 minutes \\
Exhaust gas concentration & $C_{\mathrm{e}, \mathrm{x}}$ & $\mathrm{ppm}$ & 4 & 2 hours \\
Outdoor gas concentration & $C_{\mathrm{o}, \mathrm{x}}$ & $\mathrm{ppm}$ & 2 & 2 hours \\
Gas concentration (center) & $C_{\mathrm{c}, \mathrm{x}}$ & $\mathrm{ppm}$ & 2 & 2 hours
\end{tabular}




$$
\mathrm{Pa}
$$

277

278

279

280

281

282

286

\subsection{Calculation process}

\subsubsection{Estimation of the increased ventilation flow rate to fulfil the gas concentration requirements}

In Fig. 2 the calculation process adopted in this work is resumed and the calculation steps are presented. In all the calculations, the monitored gas emissions are considered constant in the hourly time step.

At each hourly time step $j$, the indoor gas concentrations should be maintained below the established thresholds. This condition is expressed using the following inequation that must be fulfilled for both $\mathrm{NH}_{3}$ and $\mathrm{CO}_{2}$

$$
\bar{C}_{\mathrm{i}, \mathrm{x}, \mathrm{j}} \leq C_{\lim , \mathrm{x}}
$$

where $\bar{C}_{\mathrm{i}, \mathrm{x}, \mathrm{j}}$ is the average mass concentration of the analysed gas $x$ (subscript $x$ ) inside the building (subscript $i$ ) at time step $j$. The value of $\bar{C}_{\mathrm{i}, \mathrm{x}, \mathrm{j}}$ is the arithmetic mean between the average value of the two measured $C_{\mathrm{c}, \mathrm{x}, \mathrm{j}}$, and the average value of the four measured $C_{\mathrm{e}, \mathrm{x}, \mathrm{j}}$. The term $C_{\text {lim, } \mathrm{x}}$ is the mass concentration limit (subscript lim) of gas $x$.

If the constraint of Eq. (1) is respected, the actual ventilation flow rate of large $\left(\dot{V}_{\mathrm{l}, \mathrm{j}}\right)$ and small $\left(\dot{V}_{\mathrm{s}, \mathrm{j}}\right)$ fans is calculated on the basis of the real monitored data $\left(\omega_{\mathrm{l}}, \omega_{\mathrm{s}}\right.$ and $\left.\Delta p\right)$, according to the method described in Calvet, Cambra-López, Blanes-Vidal, Estellés, and Torres (2010). The total actual ventilation flow rate $\left(\dot{V}_{\mathrm{l}+\mathrm{s}, \mathrm{j}}\right)$ is the sum of $\dot{V}_{\mathrm{l}, \mathrm{j}}$ and $\dot{V}_{\mathrm{s}, \mathrm{j}}$. The obtained values of $\dot{V}_{\mathrm{l}, \mathrm{j}}, \dot{V}_{\mathrm{s}, \mathrm{j}}$ and $\dot{V}_{\mathrm{l}+\mathrm{s}, \mathrm{j}}$ are used to calculate the fan electrical energy consumption $\left(E_{\mathrm{el}, \mathrm{l}+\mathrm{s}}\right)$ through the $S F P$, while the needed heating load $\left(\Phi_{\mathrm{H}, \mathrm{j}}\right)$ and the thermal energy consumption for supplemental heating $\left(E_{\mathrm{th}}\right)$ are calculated through the energy simulation model.

If the constraint of Eq. (1) is not respected, the theoretical increased ventilation flow rate $\left(\dot{V}_{1+\mathrm{s}, \mathrm{x}, \mathrm{j}}^{\prime}\right)$ needed to guarantee $C_{\mathrm{lim}, \mathrm{x}}$ has to be calculated. At each time step $j, \dot{V}_{\mathrm{l}+\mathrm{s}, \mathrm{x}, \mathrm{j}}^{\prime}$ depends on the gas emission rate from internal sources $\left(\dot{q}_{\mathrm{x}, \mathrm{j}}\right)$, such as the reared broilers and the bedding material. At each time step $j, \dot{q}_{\mathrm{x}, \mathrm{j}}$ reads 


$$
\dot{q}_{\mathrm{x}, \mathrm{j}}=\left(\bar{C}_{\mathrm{i}, \mathrm{x}, \mathrm{j}}-\bar{C}_{\mathrm{o}, \mathrm{x}, \mathrm{j}}\right) \cdot \frac{m_{\mathrm{x}}}{V_{\mathrm{mol}, \mathrm{x}}} \cdot \dot{V}_{\mathrm{l}+\mathrm{s}, \mathrm{j}} \quad\left[\frac{\mathrm{mg}_{\mathrm{x}}}{\mathrm{h}}\right]
$$

301 where $\bar{C}_{\mathrm{o}, \mathrm{x}, \mathrm{j}}$ (in ppm) is the is the average outdoor (subscript $o$ ) concentration of gas $x$ at

302

303

304

305

306

307

308

309

310

311

312

313

314

315

316

317

318

319

320

hourly time step $j$, obtained as the arithmetic mean between the two monitored values of $C_{\mathrm{o}, \mathrm{x}, \mathrm{j}}$. $m_{\mathrm{x}}$ is the molecular mass of gas $x$ that is equal to $0.017031 \mathrm{~kg} \mathrm{~mol}^{-1}$ for $\mathrm{NH}_{3}$ and $0.04401 \mathrm{~kg} \mathrm{~mol}^{-1}$ for $\mathrm{CO}_{2} . V_{\mathrm{mol}}$ is the molar volume of gas $x$, that in this work is considered constant and equal to $0.02445 \mathrm{~m}^{3} \mathrm{~mol}^{-1}$ for $\mathrm{NH}_{3}$ and $\mathrm{CO}_{2} . \dot{V}_{\mathrm{l}+\mathrm{s}, \mathrm{j}}$ is the actual ventilation flow rate, calculated using the real monitored data calculated as previously stated. In Eq. (2), some simplifications are assumed, since $\dot{q}_{\mathrm{x}, \mathrm{j}}$ is considered constant and not influenced by the variation of the indoor environmental conditions in the considered time step $j$.

Once estimated $\dot{q}_{\mathrm{x}, \mathrm{j}}, \dot{V}_{\mathrm{l}+\mathrm{s}, \mathrm{x}, \mathrm{j}}^{\prime}$ is calculated through the following gas mass balance in steadystate conditions

$$
\dot{V}_{\mathrm{l}+\mathrm{s}, \mathrm{x}, \mathrm{j}}^{\prime}=\frac{\dot{q}_{\mathrm{x}, \mathrm{j}}}{C_{\mathrm{lim}, \mathrm{x}}-\bar{C}_{\mathrm{o}, \mathrm{x}, \mathrm{j}}} \cdot \frac{V_{\mathrm{mol}, \mathrm{x}}}{m_{\mathrm{x}}} \quad\left[\frac{\mathrm{m}^{3}}{\mathrm{~h}}\right]
$$

Eqs. (2) and (3) are applied at each time step of the analysed period for which the constraint of Eq. (1) is not respected. Considering $\mathrm{NH}_{3}$ and $\mathrm{CO}_{2}$ in Eqs. (2) and (3), $\dot{V}_{1+s, \mathrm{NH}_{3}, \mathrm{j}}^{\prime}$ and $\dot{V}_{1+s, \mathrm{CO}_{2}, \mathrm{j}}^{\prime}$ are obtained, respectively. At the time step $j$, the total theoretical ventilation flow rate $\left(\dot{V}_{1+s, j}^{\prime}\right)$ is calculated as

$$
\dot{V}_{\mathrm{l}+\mathrm{s}, \mathrm{j}}^{\prime}=\max \left\{\dot{V}_{\mathrm{l}+\mathrm{s}, \mathrm{NH}_{3}, \mathrm{j}}^{\prime} ; \dot{V}_{\mathrm{l}+\mathrm{s}, \mathrm{CO}_{2}, \mathrm{j}}^{\prime}\right\} \quad\left[\frac{\mathrm{m}^{3}}{\mathrm{~h}}\right]
$$

The obtained $\dot{V}_{\mathrm{l}+\mathrm{s}, \mathrm{j}}^{\prime}$ is split into the flow rate provided by large $\left(\dot{V}_{\mathrm{l}, \mathrm{j}}^{\prime}\right)$ and small fans $\left(\dot{V}_{\mathrm{s}, \mathrm{j}}^{\prime}\right)$ according to the control logic of the automatic climate control system of the broiler house (below 75,000 $\mathrm{m}^{3} \mathrm{~h}^{-1}$ only small fans are activated). The obtained values of $\dot{V}_{\mathrm{l}+\mathrm{s}, \mathrm{j}}^{\prime}, \dot{V}_{\mathrm{l}, \mathrm{j}}^{\prime}$ and $\dot{V}_{\mathrm{s}, \mathrm{j}}^{\prime}$ are used to calculate the fan electrical energy consumption $\left(E_{\mathrm{el}, \mathrm{l}+\mathrm{s}}^{\prime}\right)$, the theoretical heating $\operatorname{load}\left(\Phi_{\mathrm{H}, \mathrm{j}}^{\prime}\right)$, the simulated indoor air temperature $\left(\theta_{\mathrm{air}, \mathrm{i}}^{\prime}\right)$ and the thermal energy consumption for heating $\left(E_{\mathrm{th}}^{\prime}\right)$, as described in the following section. 


\subsubsection{Estimation of the electrical and thermal energy consumption}

322 The estimation of the electrical energy consumption due to ventilation was carried out

323 characterizing each fan model with the $S F P$ curve. The $S F P$ of a generic fan represents the

324

325

326

327

328

329

330

331

332

333

334 energy needed by the fan to provide a cubic meter of airflow. For a generic fixed propeller speed fan, Costantino et al. (2018) expressed the SFP as a function of the static pressure difference between inside and outside of the house $\Delta p$ as

$$
S F P_{\text {fan }}=b_{2} \cdot \Delta p^{2}+b_{1} \cdot \Delta p+b_{0} \quad\left[\frac{\mathrm{m}^{3}}{\mathrm{Wh}}\right]
$$

where $b_{2}, b_{1}$ and $b_{0}$ are empirical coefficients that in this work are obtained by a regression from the technical datasheets of the fans.

Values of $b_{2}, b_{1}$ and $b_{0}$ are presented in Table 3 for both fan models.

Table 3 - Regression coefficients $b_{2}, b_{1}$ and $b_{0}$ for the $S F P$ of both the fan models.

\begin{tabular}{cccc}
\hline Fan model & Coefficient & Value & Unit \\
\hline \multirow{2}{*}{ Large fans } & $b_{\mathrm{l}, 2}$ & $-5.0000 \cdot 10^{-8}$ & $\mathrm{~m}^{3} \mathrm{Wh}^{-1} \mathrm{~Pa}^{-2}$ \\
& $b_{\mathrm{l}, 1}$ & $+2.0250 \cdot 10^{-4}$ & $\mathrm{~m}^{3} \mathrm{Wh}^{-1} \mathrm{~Pa}^{-1}$ \\
& $b_{\mathrm{l}, 0}$ & +0.0316 & {$[-]$} \\
\hline \multirow{2}{*}{ Small fans } & $b_{\mathrm{s}, 2}$ & 0 & $\mathrm{~m}^{3} \mathrm{Wh}^{-1} \mathrm{~Pa}^{-2}$ \\
& $b_{\mathrm{s}, 1}$ & $+3.7110 \cdot 10^{-5}$ & $\mathrm{~m}^{3} \mathrm{Wh}^{-1} \mathrm{~Pa}^{-1}$ \\
& $b_{\mathrm{s}, 0}$ & +0.0486 & {$[-]$} \\
\hline
\end{tabular}

The electrical energy consumption due to the actual ventilation $\left(E_{\mathrm{el}, \mathrm{l}+\mathrm{s}}\right)$ of the analysed period is calculated as

$$
E_{\mathrm{el}, \mathrm{l}+\mathrm{s}}=\left[\sum_{\mathrm{j}=1}^{967}\left(\frac{\dot{V}_{\mathrm{l}, \mathrm{j}}}{S F P_{\mathrm{l}}}+\frac{\dot{V}_{\mathrm{s}, \mathrm{j}}}{S F P_{\mathrm{s}}}\right)\right] \cdot 10^{-3} \quad\left[\mathrm{kWh}_{\mathrm{el}}\right]
$$

335 where $\dot{V}_{\mathrm{l}, \mathrm{j}}$ and $\dot{V}_{\mathrm{s}, \mathrm{j}}$ are the actual ventilation flow rates provided the large and small fans at the 336 time step $j, S F P_{1}$ and $S F P_{\mathrm{s}}$ are the $S F P$ of large and small fans respectively, and 967 is the number of hours of the analysed period.

338 In a similar way, the electrical energy consumption due to the increased ventilation $\left(E_{\mathrm{el}, 1+\mathrm{s}}^{\prime}\right)$ is 339 calculated as 


$$
E_{\mathrm{el}, \mathrm{l}+\mathrm{s}}^{\prime}=\left[\sum_{\mathrm{j}=1}^{967}\left(\frac{\dot{V}_{\mathrm{l}, \mathrm{j}}^{\prime}}{S F P_{\mathrm{l}}}+\frac{\dot{V}_{\mathrm{s}, \mathrm{j}}^{\prime}}{S F P_{\mathrm{s}}}\right)\right] \cdot 10^{-3} \quad[\mathrm{kWh} \mathrm{el}]
$$

The estimation of the thermal energy consumption was carried out by the application of the dynamic energy simulation model developed by Costantino, Fabrizio, Ghiggini, and Bariani (2018). This model was specifically developed for mechanically ventilated broiler houses and is in compliance with ISO 13790 standard (2008). The adopted simulation model estimates the indoor environmental conditions $\left(\theta_{\mathrm{air}, \mathrm{i}}\right.$ and $\left.R H_{\mathrm{i}}\right)$ and the thermal and electrical energy consumption for climate control by solving a resistance-capacitance electrical network that is equivalent to the analysed building. The electrical network has 5 resistances and 1 capacitance (5R1C) and is solved using a finite difference method (Crank-Nicolson scheme) that analyses the 5R1C network with a time discretization of one hour. The reliability of the application of this model to broiler house was proven by previous works (Costantino et al., 2018; Costantino, Ballarini, Fabrizio, 2017).

In the framework of this paper, the energy simulation model of Costantino et al. (2018) is used for estimating the thermal energy consumption $\left(E_{\mathrm{th}}\right)$ considering the actual ventilation and the thermal energy consumption $\left(E_{\mathrm{th}}^{\prime}\right)$ considering the thoeretical ventilation needed to maintain $C_{\mathrm{lim}, \mathrm{NH}_{3}}$ and $C_{\lim , \mathrm{CO}_{2}}$. The simulations were performed for the 967 hours of the monitoring period with an hourly time step.

To calculate $E_{\text {th }}$ and $E_{\text {th }}^{\prime}$, the boundary conditions of the analysed case study were inputted in the model, in particular:

- the geometrical and the thermophysical properties (e.g. $U$-values and $\kappa_{\mathrm{i}}$ ) of the analysed broiler house;

- the farming features (e.g. stocking density and duration of the production cycle); the broiler weight was expressed as a function of the time based on the monitored data of $w_{\mathrm{b}}$;

- the outdoor weather conditions of $\theta_{\text {air,o }}$ and $I_{\text {tot,hor }}$ (obtained from a third-party weather station);

- the main features of the climate control system (e.g. control logic of the fans and $\left.\eta_{\mathrm{H}}\right)$

- the $\theta_{\text {set,H }}$ adopted in the case study $\left(31^{\circ} \mathrm{C}\right.$ at the beginning and $18{ }^{\circ} \mathrm{C}$ at the end of the production cycle). 
369 Finally, $\dot{V}_{\mathrm{l}+\mathrm{s}}$ and $\dot{V}_{\mathrm{l}+\mathrm{s}}^{\prime}$ were input into the model to obtain $E_{\mathrm{th}}$ and $E_{\mathrm{th}}^{\prime}$, respectively.

\section{Results and discussion}

\subsection{Analysis of the monitored data}

372 In Fig. 3a, the hourly values of $\theta_{\text {air, } i}$ and $\theta_{\text {air,o }}$ during the monitored period are shown. The

373 pattern of $\theta_{\text {air,i }}$ strictly followed the settings of the automatic control system of the farm and it can be considered similar to those obtained in other regions with different outdoor climate conditions (Jones, Donnelly, Stamp Dawkins, 2005.). At the beginning of the monitored period, (December $22^{\text {nd }}$, the $8^{\text {th }}$ day of the production cycle) $\theta_{\text {air,i }}$ had an average daily value of around $27^{\circ} \mathrm{C}$; during the production cycle, $\theta_{\text {air,i }}$ gradually decreased reaching an average daily value of around $18{ }^{\circ} \mathrm{C}$ at the end of the production cycle (January $31^{\text {st }}$ ). This decreasing trend had an exception on January $19^{\text {th }}$, when $\theta_{\text {air,i }}$ was considerably higher than in the previous days. This $\theta_{\text {air,i }}$ peak was caused by $\theta_{\text {air,o }}$ that reached the highest value $\left(26^{\circ} \mathrm{C}\right)$ of the entire monitored period on that day. Before January $19^{\text {th }}$, the trend of $\theta_{\text {air,o }}$ was quite

382

383 constant daily, and the average value of the period from December $22^{\text {nd }}$ to January $18^{\text {th }}$ was around $10^{\circ} \mathrm{C}$. After the peak of January $19^{\text {th }}, \theta_{\text {air,o }}$ remained higher than in the previous days with an average daily value of around $14.5^{\circ} \mathrm{C}$ (January $\left.19^{\text {th }}-21^{\text {st }}\right)$. From January $22^{\text {nd }}$ to the end of the monitored period, $\theta_{\text {air,o }}$ decreased to an average value of $7.6{ }^{\circ} \mathrm{C}$.

The trend of the total actual ventilation flow rate $\dot{V}_{\mathrm{l}+\mathrm{s}}$ during the monitored period is presented in Fig. 3b. From the beginning of the monitored period to January $18^{\text {th }}, \dot{V}_{\mathrm{l}+\mathrm{s}}$ gradually increased. On January $18^{\text {th }}$, a considerable increase in $\dot{V}_{1+\mathrm{s}}$ can be noticed and a peak of about $266,000 \mathrm{~m}^{3} \mathrm{~h}^{-1}$ (the maximum monitored value of $\dot{V}_{\mathrm{l}+\mathrm{s}}$ ) occurred on January $19^{\text {th }}$, corresponding to the sudden increase of $\theta_{\text {air }, o}$. From January $22^{\text {nd }}$ to the end of the production cycle, $\dot{V}_{\mathrm{l}+\mathrm{s}}$ falls off due to the decrease of $\theta_{\mathrm{air}, \mathrm{o}}$ during the last days and due to the reduction of the number of broilers ( $15 \%$ of them was harvested on January $24^{\text {th }}$ ).

The actual ventilation flow rate can be expressed in air changes per hour (ach). During the monitored period, the minimum ventilation flow rate was around 1 ach, the maximum one was higher than 50 ach while the average was around 9 ach.

As stated before, intensive broiler farms usually are designed, equipped and operated to maintain the adequate indoor air temperature to ensure an optimum animal development but, on the contrary, farm installations are not usually designed and operated to maintain established $\mathrm{NH}_{3}$ and $\mathrm{CO}_{2}$ concentration levels. Consequently, concentration thresholds are 
normally exceeded in winter periods, when ventilation rates are low, as evidenced by Groot Koerkamp et al. (1998) and by the monitored emission trend presented in Fig. 3c and d. In Fig. $3 c$, the monitored $\mathrm{NH}_{3}$ mass concentration is presented. During the analysed period, $\bar{C}_{\mathrm{O}_{\mathrm{NH}}}$ remained quite constant with an average value (during the entire period) lower than $1 \mathrm{ppm} . \bar{C}_{\mathrm{i}, \mathrm{NH}_{3}}$ had an average value of $18.3 \mathrm{ppm}$ (the minimum was $1.4 \mathrm{ppm}$, the maximum $38.1 \mathrm{ppm}$ ) but it varied considerably and exceeded the threshold mainly in the central portion of the monitored period. Although this tendency is also described in literature (Knížatová et al., 2010), the evolution of $\mathrm{NH}_{3}$ concentration is, to some extent, hard to predict, being influenced by litter management, environmental conditions, ventilation rates and broiler health status (Weaver and Meijerhof, 1991). In Fig. 3c it stands out that during the first days, $\bar{C}_{\mathrm{i}, \mathrm{NH}_{3}}$ was considerably below the $\bar{C}_{\mathrm{lim}, \mathrm{NH}_{3}}$ but, later, it sudden increased since the chicks were growing and because the excreta quantity in the bedding material increased over time, affecting the $\mathrm{NH}_{3}$ emissions. From December $28^{\text {th }}$ to January $18^{\text {th }}, \bar{C}_{\mathrm{i}, \mathrm{NH}_{3}}$ remained higher than $C_{\lim , \mathrm{NH}_{3}}$ for most of the time. After January $18^{\text {th }}$ to the end of the production cycle, the increased $\dot{V}_{\mathrm{l}+\mathrm{s}}$ (due to the high values of $\theta_{\mathrm{air}, \mathrm{o}}$ ) improved the indoor environmental conditions in terms of gas concentration, and $\bar{C}_{\mathrm{i}, \mathrm{NH}_{3}}$ decreased below $C_{\mathrm{lim}, \mathrm{NH}_{3}}$ for most of the time. The reduction of the animal stocking density inside the house of January $24^{\text {th }}$ may have partially affected this decrease.

Despite $\mathrm{CO}_{2}$ production from broilers and manure increases as broilers grow (Calvet, Estelles, Cambra-Lopez, Torres, Van den Weghe, 2011), $\mathrm{CO}_{2}$ concentrations inside the house followed a decreasing trend in the analysed period due to the diluting effect of increasing ventilation rates. During the first days of the monitored period, $\bar{C}_{\mathrm{i}, \mathrm{CO}_{2}}$ had higher values than in the remaining days and was considerably higher than $C_{\mathrm{lim}, \mathrm{CO}_{2}}$, as shown in Fig. 3d. This difference was due to the need to maintain $\theta_{\mathrm{set}, \mathrm{H}}$ during the first days of the production cycle. Combining the high temperature needs of broilers during their first days of life with their low sensible thermal emission, supplemental heating had to be provided to reach $\theta_{\mathrm{set}, \mathrm{H}}$. The supplemental heating was provided by propane air heaters that emitted the exhaust fumes directly inside the enclosure, increasing $\theta_{\mathrm{air}, \mathrm{i}}$ and $\bar{C}_{\mathrm{i}, \mathrm{CO}_{2}}$. During these days (December $22^{\text {nd }}-$ January $6^{\text {th }}$ ), $\dot{V}_{\mathrm{l}+\mathrm{s}}$ was at minimum values (below $50,000 \mathrm{~m}^{3} \mathrm{~h}^{-1}$ ) and the $\mathrm{CO}_{2}$ in the house could not be diluted through the ventilation. When $\theta_{\text {set,H }}$ was maintained without the supplemental heating, $\bar{C}_{\mathrm{i}, \mathrm{CO}_{2}}$ decreased considerably and after January $6^{\text {th }}$ remained stably below $C_{\mathrm{lim}, \mathrm{CO}_{2}}$. During the monitored period, the average value of $\bar{C}_{\mathrm{i}, \mathrm{CO}_{2}}$ was $2,517 \mathrm{ppm}$ (the 
minimum was $819 \mathrm{ppm}$, the maximum 5,765 ppm), while the average value of $\bar{C}_{\mathrm{i}, \mathrm{CO}_{2}}$ was around $480 \mathrm{ppm}$ and it was almost constant. The outdoor concentration $\bar{C}_{\mathrm{O}, \mathrm{CO}_{2}}$ had a mean value of $484 \mathrm{ppm}$ during the monitoring period, with the minimum value of $430 \mathrm{ppm}$ and the maximum one of $763 \mathrm{ppm}$.

The absolute and cumulative frequencies of $\bar{C}_{\mathrm{i}, \mathrm{NH}_{3}}$ and $\bar{C}_{\mathrm{i}, \mathrm{CO}_{2}}$ are presented in Fig. $4 \mathrm{a}$ and b, respectively. Comparing the trends of the two cumulative frequencies, the control of $\bar{C}_{\mathrm{i}, \mathrm{NH}_{3}}$ appears more problematic than the control of $\bar{C}_{\mathrm{i}, \mathrm{CO}_{2}}$. Analysing separately the concentrations of $\mathrm{NH}_{3}$ and $\mathrm{CO}_{2}$, it stands out that $43 \%$ of the $\bar{C}_{\mathrm{i}, \mathrm{NH}_{3}}$ values are above $20 \mathrm{ppm}$, while around $30 \%$ of the $\bar{C}_{\mathrm{i}, \mathrm{CO}_{2}}$ values result above $3,000 \mathrm{ppm}$. Considering the analysed gas concentration together, $\bar{C}_{\mathrm{i}, \mathrm{NH}_{3}}$ and $\bar{C}_{\mathrm{i}, \mathrm{CO}_{2}}$ are below their thresholds only for $40 \%$ of the monitored time, therefore for $60 \%$ of time the gas concentration limits were not respected in the monitored broiler house.

The negative effects of a stressor on the animal's welfare are dependent on both its severity and its duration (Gerritzen, Lambooij, Hillebrand, Lankhaar, Pieterse, 2000; Ritz, Fairchild, Lacy, 2004). Although acute exposure to lethal concentrations of gases may occur in livestock buildings, the effects of chronic exposure are more insidious (Wathes and Charles, 1994). For example, a long exposure to $\mathrm{NH}_{3}$ (around 42 days) at $20 \mathrm{ppm}$ (the concentration limit) may cause pulmonary congestion, oedema and haemorrhage (Anderson, Beard, Hanson 1964; Quarles and Kling, 1974). Broilers exposed to 25 and $50 \mathrm{ppm}$ of $\mathrm{NH}_{3}$ concentration for 35 days increased the respiratory rate, the haemoglobin and haematocrit, which could indicate an increase in the metabolic activity to meet energy demands under stressful situations (Olanrewaju et al., 2007). For this reason, it is important to consider both the concentration values and the exposure time. In Table 4, the number of events (periods of time in which the gas concentration limit is continuously exceeded) and their duration (time in which the gas concentration is continuously above the established limit) are reported. The number of events in which $C_{\lim , \mathrm{NH}_{3}}$ was exceeded in the monitored period was 30. About half of these events (14) lasted less than 8 hours with maximum $\bar{C}_{\mathrm{i}, \mathrm{NH}_{3}}$ values lower than $27 \mathrm{ppm}$, while 11 events lasted more than 18 hours reaching concentration values considerably higher than $C_{\lim , \mathrm{NH}_{3}}$ (e.g. 36.5 and $38.1 \mathrm{ppm}$ ). Such high concentration may have a deleterious effect on growth (Beker et al., 2004; Valentine, 1964; Quarles and Kling, 1974), may cause alterations in blood physiological parameters (Olanrewaju et al., 2007) and aversion to atmospheres (Kristensen, Burgess, Demmers, Wathes, 2000; Wathes, Jones, Kristensen, Jones, Webster, 2002). 
464 The number of events in which $\bar{C}_{\mathrm{i}, \mathrm{CO}_{2}}$ exceeded $C_{\mathrm{lim}, \mathrm{CO}_{2}}$ was 12 : in 5 of them the duration was higher than 18 hours with concentrations considerably higher than the limit (up to $5,796 \mathrm{ppm}$ of maximum value). These high concentrations can be considered tolerated by broilers if intermittent (Verstegen, Tamminga, Greers, 1994), otherwise they represent a risk for the animal health.

According to literature, it seems easy for most of the farms to maintain $\mathrm{CO}_{2}$ levels below the limits that can cause damages to the broilers (Olanrewaju et al., 2008). The results reported in Fig. 4 and Table 4 confirm what stated in literature; in the analysed case study the control of $\mathrm{CO}_{2}$ concentration was easier than the one of $\mathrm{NH}_{3}$.

Table 4 - Number of events and duration in which the indoor average $\mathrm{NH}_{3}\left(\bar{C}_{\mathrm{i}, \mathrm{NH}_{3}}\right)$ and $\mathrm{CO}_{2}\left(\bar{C}_{\mathrm{i}, \mathrm{CO}_{2}}\right)$ concentrations exceeded the established thresholds.

\begin{tabular}{ccccc}
\hline \multirow{2}{*}{$\begin{array}{c}\text { Duration } \\
\text { [h] }\end{array}$} & \multicolumn{3}{c}{$\mathrm{NH}_{3}$} & \multicolumn{2}{c}{$\mathrm{CO}_{2}$} \\
\cline { 2 - 5 } & Number of events & $\begin{array}{c}\text { Maximum } \bar{C}_{\mathrm{i}, \mathrm{NH}_{3}} \\
\text { [ppm] }\end{array}$ & Number of events & $\begin{array}{c}\text { Maximum } \bar{C}_{\mathrm{i}, \mathrm{CO}_{2}} \\
\text { [ppm] }\end{array}$ \\
\hline From 2 to 4 & 7 & 22.3 & 2 & 3,121 \\
From 6 to 8 & 7 & 27.0 & 1 & 3,101 \\
From 10 to 12 & 1 & 22.0 & 1 & 3,178 \\
From 14 to 16 & 4 & 33.1 & 3 & 3,508 \\
From 18 to 20 & 9 & 36.5 & 2 & 4,113 \\
From 22 to 24 & 0 & - & 2 & 4,744 \\
More than 24 & 2 & 38.1 & 1 & 5,796 \\
\hline Total & 30 & & 12 & \\
\hline
\end{tabular}

\subsection{Evaluation of the theoretical ventilation increase}

As described in the previous sections, during the monitored period, the thresholds of $\mathrm{NH}_{3}$ and $\mathrm{CO}_{2}$ were exceeded repeatedly, with various time durations. In the case study, the adopted strategy to reduce those concentrations is to increase the ventilation rate. In other words, gas concentrations were used as additional control parameters of ventilation (in addition to $\theta_{\text {air,i }}$ that is commonly used), and the required ventilation was modelled assuming a constant emission rate of $\mathrm{NH}_{3}$ and $\mathrm{CO}_{2}$. Although other options are also available, this strategy may be the most readily convenient for a farmer. A critical assumption of the approach in this study is that gas emissions do not differ for different ventilation rates. Despite it is known that $\mathrm{NH}_{3}$ emissions are affected by airflow rates and patterns (Morsing, Strom, Zhang, Kai, 2008), the effect of changing ventilation rate on gas emissions is unclear in research. On the one hand, Knížatová et al. (2010) suggested that higher ventilation is the reason of increased emissions 
in summer. However, higher ventilation rates at certain air temperature and relative humidity also contribute to litter drying thus reducing the emission of $\mathrm{NH}_{3}$ (Weaver and Meijerhof, 1991). There is no evidence of variations in $\mathrm{CO}_{2}$ emissions due to changes in ventilation rates, and therefore the hypothesis of constant emission of this gas seems adequate. Furthermore, the variation in percentage between $\dot{V}_{\mathrm{l}+\mathrm{s}}$ and $\dot{V}_{\mathrm{l}+\mathrm{s}}^{\prime}$ is generally small, being lower than $60 \%$ in $90 \%$ of the considered time steps. In the primary axis of Fig. 5 the relative variation between $\dot{V}_{\mathrm{l}+\mathrm{s}}^{\prime}$ and $\dot{V}_{\mathrm{l}+\mathrm{s}}$ is shown expressed as a percentage. From the graph it stands out that during the first days the difference in percentage is higher than in the following ones, reaching its maximum value (116\%). After the first days, the difference decreases, and a further increase can be noticed in the half of the monitored period. To better understand the trend of the increased ventilation flow rate, the absolute variation between $\dot{V}_{1+\mathrm{s}}^{\prime}$ and $\dot{V}_{\mathrm{l}+\mathrm{s}}\left(\Delta \dot{V}_{\mathrm{l}+\mathrm{s}}^{\prime}\right)$ is analysed. This trend is reported in the secondary axis of Fig. 5 and it is expressed in $\mathrm{m}^{3} \mathrm{~h}^{-1}$. The graph shows that $\Delta \dot{V}_{1+s}^{\prime}$ is higher from January $7^{\text {th }}$ to $18^{\text {th }}$, when peaks that exceed $25,000 \mathrm{~m}^{3} \mathrm{~h}^{-1}$ are present. These considerable values of $\Delta \dot{V}_{1+s}^{\prime}$ depend on the increase of $\bar{C}_{\mathrm{i}, \mathrm{NH}_{3}}$ that characterizes those days (as reported in Fig. 3c). From January $19^{\text {th }}$ to the end of the cycle, $\Delta \dot{V}_{1+s}^{\prime}$ is not needed because higher values of $\dot{V}_{1+s}$ were monitored due to the increase of $\theta_{\text {air,o }}$. The only exception is from January $24^{\text {th }}$ to $30^{\text {th }}$ when the decrease of $\theta_{\text {air, } o}$ entails a reduction in $\dot{V}_{\mathrm{l}+\mathrm{s}}$ that is not enough to maintain $\bar{C}_{\mathrm{i}, \mathrm{NH}_{3}}$ below the established limit. From the beginning of the monitored period to January $6^{\text {th }}, \Delta \dot{V}_{1+s}^{\prime}$ values rarely exceed $10,000 \mathrm{~m}^{3} \mathrm{~h}^{-1}$. These increases in ventilation are needed to dilute the high $\mathrm{CO}_{2}$ concentration of those day that are caused by the low values of $\dot{V}_{1+\mathrm{s}}$ and the activation of the propane air heaters that emit exhaust fumes directly inside the house.

In this work, the increased ventilation flow rate was calculated considering each gas emission $\dot{q}_{\mathrm{x}}$ constant and not influenced by the variation of the indoor environmental conditions. A future improvement of the present work may involve the evaluation of the theoretical increase of the ventilation flow rate considering a not constant gas emission but considering different parameters that influence $\mathrm{NH}_{3}$ and $\mathrm{CO}_{2}$ emissions, such as the litter conditions.

In the present work, the extra ventilation flow rate to control gas concentration was calculated considering that the extra supplemental heat needed to maintain $\theta_{\mathrm{set}, \mathrm{H}}$ is provided by systems that do not emit exhaust fumes inside the house and, consequently, do not further increase the $\mathrm{CO}_{2}$ concentration. Anyway, it was verified that if the supplemental heat would be provided by the same propane heaters that are present inside the analysed livestock house, the emitted exhaust fumes are estimated to increase the $\mathrm{CO}_{2}$ concentration by less than $3 \%$ on average. 
This is because the $\mathrm{CO}_{2}$ emissions from broilers are considerably higher than the one from the propane air heaters.

\subsection{Evaluation of the energy consumptions}

The analysis shows that during the monitored period around 41,900,000 $\mathrm{m}^{3}$ of fresh air were provided by the fans to the broiler house. To maintain the required gas concentration during all the monitored period, around 45,800,000 $\mathrm{m}^{3}$ of fresh air are theoretically needed, an increase by about $9.3 \%$. This increase in ventilation flow rate makes it possible to respect the established gas concentration threshold but, at same time, entails a rise of the energy consumption of both electrical energy (for operating the fans) and thermal energy (for maintaining $\theta_{\text {set,H }}$ ). In Table 5 the thermal and electrical energy consumption considering $\dot{V}_{\mathrm{l}+\mathrm{s}}$ and $\dot{V}_{\mathrm{l}+\mathrm{s}}^{\prime}$ are presented and compared. From the table it stands out that considering the increased ventilation, the electrical energy consumption rises from $1,946 \mathrm{kWh}_{\mathrm{el}}\left(E_{\mathrm{el}, \mathrm{l}+\mathrm{s}}\right)$ to $2,137 \mathrm{kWh}_{\mathrm{el}}\left(E_{\mathrm{el}, \mathrm{l}+\mathrm{s}}^{\prime}\right)$, an increase by $9.8 \%$. Focusing on the share of the electrical energy consumption of large and small fans, the table shows that, on the one hand, the electrical energy consumption of the small fans increases by about $11.5 \%$, rising from $1,689 \mathrm{kWh}_{\mathrm{el}}$ $\left(E_{\mathrm{el}, \mathrm{s}}\right)$ to $1,883 \mathrm{kWh}\left(E_{\mathrm{el}, \mathrm{s}}^{\prime}\right)$. On the other hand, the electrical energy consumption due to the operation of large fans slightly decreases by $1.2 \%$, from $257 \mathrm{kWh}_{\mathrm{el}}\left(E_{\mathrm{el}, \mathrm{l}}\right)$ to $254 \mathrm{kWh}_{\mathrm{el}}\left(E_{\mathrm{el}, \mathrm{l}}^{\prime}\right)$.

This slight decrease depends on the control logic that is set in the climate control system for activating the fans. Most of the estimated values of $\dot{V}_{1+s}^{\prime}$, in fact, are below the threshold of activation of the large fans $\left(75,000 \mathrm{~m}^{3} \mathrm{~h}^{-1}\right)$ and the increased ventilation flow rate is provided almost only by the small fans which energy consumption increases. Little differences between the real control logic of the fans and the modelled one may exist, and they may slightly affect the results.

The increase of ventilation air flow rate entails also an increase in the thermal energy consumption for heating, as reported in Table 5. During the monitored period, the energy simulation model estimates $E_{\mathrm{th}}$ to be around $31,816 \mathrm{kWh}_{\mathrm{th}}$, while considering $\dot{V}_{\mathrm{l+s}}^{\prime}, E_{\mathrm{th}}^{\prime}$ becomes $36,190 \mathrm{kWh}_{\mathrm{th}}$, an increase by $13.7 \%$.

Table 5 - Comparison between the electrical $\left(E_{\mathrm{el}}\right)$ and thermal energy consumption $\left(E_{\mathrm{th}}\right)$ considering the actual ventilation flow rate $\left(\dot{V}_{\mathrm{l}+\mathrm{s}}\right)$ and the electrical $\left(E_{\mathrm{el}}^{\prime}\right)$ and thermal energy consumption $\left(E_{\mathrm{th}}^{\prime}\right)$ considering the increased ventilation flow rate $\left(\dot{V}_{1+s}^{\prime}\right)$.

\begin{tabular}{ccc}
\hline $\begin{array}{c}\text { Energy consumption } \\
\text { considering } \dot{V}_{\mathrm{l}+\mathrm{s}}\end{array}$ & Energy consumption & Difference in percentage \\
\hline
\end{tabular}




\begin{tabular}{|c|c|c|}
\hline${ }^{1} E_{\mathrm{el}, \mathrm{l}}$ & $E_{\mathrm{el}, \mathrm{l}}^{\prime}$ & \\
\hline $257 \mathrm{kWh}_{\mathrm{el}}$ & $254 \mathrm{kWh}_{\mathrm{el}}$ & $-1.2 \%$ \\
\hline${ }^{2} E_{\mathrm{el}, \mathrm{s}}$ & $E_{\mathrm{el}, \mathrm{s}}^{\prime}$ & \\
\hline $1,689 \mathrm{kWh}_{\mathrm{el}}$ & $1,883 \mathrm{kWh}_{\mathrm{el}}$ & $+11.5 \%$ \\
\hline$E_{\mathrm{el}, \mathrm{l}+\mathrm{s}}$ & $E_{\mathrm{el}, \mathrm{l}+\mathrm{s}}^{\prime}$ & \\
\hline $1,946 \mathrm{kWh}_{\mathrm{el}}$ & $2,137 \mathrm{kWh}_{\mathrm{el}}$ & $+9.8 \%$ \\
\hline$E_{\text {th }}$ & $E_{\mathrm{th}}^{\prime}$ & \\
\hline $31,816 \mathrm{kWh}_{\mathrm{th}}$ & $36,190 \mathrm{kWh}_{\mathrm{th}}$ & +13.7 \\
\hline
\end{tabular}

550

551

552

553

554

555

556

557

558

559

560

561

562

563

564

565

566

567

568

569

570

571

572

573

The increase in thermal energy consumption is focused especially on the central part of the analysed period, as shown in Fig. 6 where the heating load needed considering $\dot{V}_{\mathrm{l}+\mathrm{s}}\left(\Phi_{\mathrm{H}}\right)$ and the theoretical heating load considering $\dot{V}_{\mathrm{l}+\mathrm{s}}^{\prime}\left(\Phi_{\mathrm{H}}^{\prime}\right)$ are shown on the primary axis. The monitored value of $\theta_{\mathrm{air}, \mathrm{i}}$, the values of $\theta_{\mathrm{set}, \mathrm{H}}, \theta_{\text {set,C }}$ and the simulated indoor air temperature $\left(\theta_{\text {air,i }}^{\prime}\right)$ are displayed on the secondary axis of the same graph. The analysis of the heating loads shows that the $\Phi_{\mathrm{H}}$ does not reach $170 \mathrm{~kW}$, that is the maximum heating load capacity of the two propane air heaters of the broiler house. The average value of $\Phi_{\mathrm{H}}$ was estimated to be around $33 \mathrm{~kW}$, with a maximum value of around $94 \mathrm{~kW}$. The average value of $\Phi_{\mathrm{H}}^{\prime}$ is not far from the one of $\Phi_{\mathrm{H}}$, being around $37 \mathrm{~kW}$, but the charts shows that $\Phi_{\mathrm{H}}^{\prime}$ trend is characterized by some peaks that are not present in $\Phi_{\mathrm{H}}$ trend, especially from January $7^{\text {th }}$ to $18^{\text {th }}$, when the highest values of $\Delta \dot{V}_{1+s}^{\prime}$ were estimated. The $\Phi_{\mathrm{H}}^{\prime}$ peaks exceed the threshold of $170 \mathrm{~kW}$ (the maximum heat capacity of the two air heaters), reaching a value around $227 \mathrm{~kW}$. It means that, adopting $\dot{V}_{\mathrm{l}+\mathrm{s}}^{\prime}$ as ventilation profile, the propane gas heaters would not be able to maintain the established $\theta_{\text {set,H }}$ during few hours of the monitored period. This aspect represents a further issue in increasing the ventilation flow rate to control gas concentration beyond the increase in energy consumption since in an existing broiler house, it may happen that the existing climate control system (air heaters and fans) would not be sized and designed to provide the needed ventilation flow rate and/or to the adequate heating load when $\mathrm{NH}_{3}$ and $\mathrm{CO}_{2}$ concentrations should be controlled.

Analysing the indoor air temperatures, the graph highlights that even though $\theta_{\text {air,i }}$ tends to fluctuate between $\theta_{\text {set,H }}$ and $\theta_{\text {set,C }}$ more than $\theta_{\text {air,i, }}^{\prime}$, the two trends are quite similar. Both $\theta_{\text {air, } \mathrm{i}}$ and $\theta_{\text {air,i }}^{\prime}$ increase considerably over $\theta_{\text {set,C }}$ on January $19^{\text {th }}$ when the peak of $\theta_{\text {air,o }}$ was monitored. On January $24^{\text {th }}$, the trends of $\theta_{\text {air,i }}$ and $\theta_{\text {air,i }}^{\prime}$ differ relevantly. This difference is 
due to the broiler harvesting operations of that day that increase the ventilation flow rate (due to door opening) decreasing $\theta_{\text {air,i }}$. This increase in the ventilation flow rate is not considered by the energy simulation model that, consequently, underestimates $\theta_{\text {air,i }}^{\prime}$. As stated before, the production of the analysed cycle was 23,212 broilers with a final live weight of 62,534 kg. Considering a carcass yield of 73\% (as stated in Costantino, Fabrizio, Biglia, Cornale and Battaglini, 2016) a total meat production of roughly $45,650 \mathrm{~kg}$ is estimated. Expressing $E_{\mathrm{el}, \mathrm{l}+\mathrm{s}}$ and $E_{\mathrm{th}}$ per unit of final product ( $\left.\mathrm{kg}_{\text {meat }}\right)$, values of $43 \mathrm{Wh}_{\text {el }} \mathrm{kg}_{\text {meat }}{ }^{-1}$ and $697 \mathrm{Wh}_{\text {th }} \mathrm{kg}_{\text {meat }}{ }^{-1}$ can be calculated, respectively. These values are comparable to the average ones found by Costantino et al., 2016, that estimated a specific energy consumption to produce a $\mathrm{kg}$ of broiler meet between 20 and $45 \mathrm{Wh}_{\mathrm{el}}$ for ventilation and between 380 and $760 \mathrm{Wh}_{\text {th }}$ for heating. Considering the increase in ventilation, the previously mentioned values would increase up to $47 \mathrm{Wh}_{\mathrm{el}}$ and $793 \mathrm{Wh}_{\mathrm{th}}$, but further analysis should be carried out for investigating how the improvement in the IAQ conditions may increase the meat production, entailing a consequent reduction of the specific energy consumption values.

In Fig. 7 the total primary energy consumption and the share due to heating and ventilation are shown for both the actual and the increased ventilation flow rates. To convert the electrical and thermal energy into primary energy, the following total conversion factors (renewable plus non-renewable energy) of Spain were used (Resolución conjunta de los Ministerios de Industria, Energía y Turismo, y Ministerio de Fomento, 2014):

- $f_{\mathrm{p}, \mathrm{tot}}=2.403\left[\mathrm{kWh}_{\mathrm{p}} \mathrm{kWh}_{\mathrm{el}}^{-1}\right]$ for the electrical energy from the grid;

- $f_{\mathrm{p}, \mathrm{tot}}=1.195\left[\mathrm{kWh}_{\mathrm{p}} \mathrm{kWh}_{\mathrm{th}}{ }^{-1}\right]$ for the natural gas.

The chart shows that the primary energy consumption considering the actual ventilation flow rate is estimated to be about $42,696 \mathrm{kWh}_{\mathrm{p}}$ with $12 \%\left(4,676 \mathrm{kWh}_{\mathrm{p}}\right)$ due to ventilation and the remaining $88 \%\left(38,020 \mathrm{kWh}_{\mathrm{p}}\right)$ due to heating. Increasing the ventilation flow rate, the primary energy consumption reaches $48,383 \mathrm{kWh}_{\mathrm{p}}$ with similar shares of energy for ventilation $5,135 \mathrm{kWh}_{\mathrm{p}}(9 \%)$ and heating $43,248 \mathrm{kWh}_{\mathrm{p}}(91 \%)$. The increase of the ventilation flow rate entails an increase by $13 \%$ in terms of total primary energy.

A last consideration concerns the financial implications of increasing the ventilation flow rate to maintain the gas concentrations below the established thresholds. Assuming a cost for the electrical energy in Spain equal to $0.14 € \mathrm{kWh}_{\mathrm{el}}{ }^{-1}$ (EUROSTAT, 2019) and $0.08 € \mathrm{kWh}_{\mathrm{th}}{ }^{-1}$ for the thermal energy from propane (IDAE, 2019) (both costs are considered excluding taxes), the total cost for climate control considering the actual ventilation flow rate is estimated to be 
607

608

609

610

611

612

613

614

615

616

617

618

619

620

621

622

623

624

625

626

627

628

629

630

631

632

633

634

635

636

637

638

$2,818 €$, meaning around $0.117 €$ per harvested broiler. Increasing the ventilation flow rate, the production cost due to the energy for climate control will increase up to $3,194 €(0.133 €$ per broiler), an increase by $14 \%$.

\section{Conclusions}

In this work, the variation of the energy consumption due to the increase of ventilation for maintaining $\mathrm{NH}_{3}$ and $\mathrm{CO}_{2}$ concentrations below established thresholds (20 and 3,000 ppm, respectively) were evaluated. A winter growing cycle of broilers in a Mediterranean broiler farm was used as a case study.

In the monitored case study, $\mathrm{NH}_{3}$ and $\mathrm{CO}_{2}$ concentrations were both below the established thresholds at the same time during $40 \%$ of time. The control of $\mathrm{CO}_{2}$ concentration represented a major issue during the first part of the analysed period, while the control of $\mathrm{NH}_{3}$ concentration was relevant during the central part of the production cycle.

To maintain the desired gas concentration, the ventilation flow rate needed to be increased by around 9\%. This resulted in electrical energy consumption increasing around $10 \%$ (from 1,946 to $2,137 \mathrm{kWh}_{\mathrm{el}}$ ), while the thermal energy increased roughly by $14 \%$, rising from $31,816 \mathrm{kWh}_{\text {th }}$ to $36,190 \mathrm{kWh}_{\text {th. }}$. The additional energy cost to maintain the gas concentration below the thresholds was estimated to be $376 €(+14 \%)$.

The methodology presented here can be used for other situations (e.g. different farm designs and climate conditions) but specific technical limitations of existing farms to provide higher ventilation rates (limited capacity of fans and heaters) should be considered. This work may be improved implementing in the adopted simulation model the short-and long-term effects of changing ventilation on $\mathrm{NH}_{3}$ and $\mathrm{CO}_{2}$ emissions.

\section{Acknowledgements}

This work was supported by the Spanish Ministry of Science and Innovation [Project GASFARM-2 AGL2008-04125].

\section{References}

ASHRAE. (2016). Standard 90.1-2016. Energy Standard for Buildings Except Low-Rise Residential Buildings. American Society of Heating, Refrigerating and Air-Conditioning Engineers, Inc. https://doi.org/http://dx.doi.org/10.1108/17506200710779521

Anderson, D.P., Beard, C.W., \& Hanson, R.P. (1964). The adverse effects of ammonia on chickens including resistance to infection with Newcastle disease virus. Avian Research, 8, 369-379. 
Beker, A., Vanhooser, S.L., Swartzlander, J.H., \& Teeter, R.G. (2004). Atmospheric Ammonia Concentration Effects on Broiler Growth and Performance. The Journal of Applied Poultry Research, 13, 5-9.

Calvet, S., Cambra-López, M., Blanes-Vidal, V., Estellés, F., \& Torres, A.G. (2010). Ventilation rates in mechanically-ventilated commercial poultry buildings in Southern Europe: Measurement system development and uncertainty analysis. Biosystems Engineering, 106, 423-432.

Calvet, S., Estelles, F., Cambra-Lopez, M., Torres, A.G., \& Van den Weghe, H.F.A. (2011). The influence of broiler activity, growth rate, and litter on carbon dioxide balances for the determination of ventilation flow rates in broiler production. Poultry Science, 90, 2449-2458.

Costantino, A., Fabrizio, E., Biglia, A., Cornale, P., \& Battaglini, L. (2016). Energy use for climate control of animal houses: the state of the art in Europe. Energy Procedia, 101, 184-191.

Costantino, A., Ballarini, I., \& Fabrizio, E. (2017). Comparison between simplified and detailed methods for the calculation of heating and cooling energy needs of livestock housing: a case study. Proceedings of the $3^{\text {rd }}$ IBPSA-Italy Conference. Bozen-Bolzano, Italy, February $8^{\text {th }}-10^{\text {th }}, 2017$.

Costantino, A., Fabrizio, E., Ghiggini, A., and Bariani, M. (2018). Climate control in broiler houses: A thermal model for the calculation of the energy use and indoor environmental conditions. Energy \& Buildings, $169,110-126$.

Costantino, A., \& Fabrizio, E. (2020). Introduction to Biosystems Engineering (N. M. Holden, M. L. Wolfe, J. A. Ogejo, \& E. J. Cummins, eds.). Blacksburg, Virginia: ASABE, VT Publishing (in press).

European Committee for Standardisation. EN ISO 15927-6: Hygrothermal performance of buildings Calculation and presentation of climatic data. , CEN $\S(2007)$.

European Council. (2007) Laying down minimum rules for the protection of chickens kept for meat production, Dir. 2007/43/CE, 28 ${ }^{\text {th }}$ June 2007.

EUROSTAT (2019). https://urlzs.com/LEao5. Accessed in May 2019.

FAO- Food and Agriculture Organization of the United Nations. (2011). Energy-smart food for people and climate - Issue Paper. Rome, Italy: FAO.

Gerritzen, M.A., Lambooij, E., Hillebrand, S.J., Lankhaar, J.A., \& Pieterse, C. (2000). Behavioral responses of broilers to different gaseous atmospheres. Poultry Science 79, 928-933.

Gerritzen, M., Lambooij, B., Reimert, H., Stegeman, A., \& Spruijt, B. (2007). A note on behaviour of poultry exposed to increasing carbon dioxide concentrations. Applied Animal Behaviour Science, 108 (1-2), $179-185$

Groot Koerkamp, P.W.G.G., Metz, J.H.M., Uenk, G.H., Phillips, V.R., Holden, M.R., Sneath, R.W., Short, J.L., White, R.P., Hartung, J., Seedorf, J., Schroder, M., Linkert, K.H., Pedersen, S., Takai, H., Johnsen, J.O., \& Wathes, C.M. (1998). Concentrations and emissions of ammonia in livestock buildings in Northern Europe. Journal of Agricultural Engineering Research, 70, 79-95.

Gustin, P., Urbain, B., Prouvost, J.F., \& Ansay, M. (1994). Effects of Atmospheric Ammonia on Pulmonary Hemodynamics and Vascular-Permeability in Pigs - Interaction with Endotoxins. Toxicology and Applied Pharmacology 125, 17-26.

IDAE (Instituto para la Diversificación y ahorro de la Energía). (2019). Informe de precios energéticos: combustibles y carburantes - Datos a 25 de marzo de 2019. 
ISO- International Standard Organization. (2008). Standard ISO 13790:2008. Energy performance of buildings Calculation of energy use for space heating and cooling.

ISO- International Standard Organization. (2017a). Standard ISO 6946:2017. Building components and building elements - Thermal resistance and thermal transmittance - Calculation methods.

ISO- International Standard Organization. (2017b). Standard ISO 13786:2017. Thermal performance of building components -- Dynamic thermal characteristics -- Calculation methods.

Jones, T.A., Donnelly, C.A., \& Stamp Dawkins, M. (2005). Environmental and Management Factors Affecting the Welfare of Chickens on Commercial Farms in the United Kingdom and Denmark Stocked at Five Densities. Poultry Science, 84, 1155-1165.

Knížatová, M., Mihina, Š., Broucek, J., Karandušovská, I., Sauter, G.J., \& Macuhová, J. (2010). Effect of the age and season of fattening period on carbon dioxide emissions from broiler housing. Czech Journal of Animal Science, 55, 436-444.

Kristensen, H.H., Burgess, L.R., Demmers, T.G.H., \& Wathes, C.M. (2000). The preferences of laying hens for different concentrations of atmospheric ammonia. Applied Animal Behaviour Science, 68, 307-318.

McGovern, R.H., Feddes, J.J.R., Zuidhof, M.J., Hanson, J.A., \& Robinson, F.E. (2001). Growth performance, heart characteristics and the incidence of ascites in broilers in response to carbon dioxide and oxygen concentrations. Canadian Biosystems Engineering, 43, 41-46.

Morsing S., Strom J.S., Zhang G., \& Kai, P. (2008). Scale model experiments to determine the effects of internal airflow and floor design on gaseous emissions from animal houses. Biosystems Engineering, 99, 99104.

Olanrewaju, H. A., Miller, W. W., Maslin, W. R., Thaxton, J. P., Dozier, W. A., Purswell, J., \& Branton, S. L. (2007). Interactive effects of ammonia and light intensity on ocular, fear and leg health in broiler chickens. International Journal of Poultry Science, 6, 762-769.

Olanrewaju, H.A., Dozier, W.A., Purswell, J.L., Branton, S.L., Miles, D.M., Lott, B.D., Pescatore, A.J., \& Thaxton, J.P. (2008). Growth Performance and Physiological Variables for Broiler Chickens Subjected to Short-Term Elevated Carbon Dioxide Concentrations. International Journal of Poultry Science, 7 , 738-742.

Oviedo-Rondón, E.O. (2010). Ahorro energético en granjas avícolas (Energy savings in poultry farms, in Spanish). Proceedings of the XLII Symposium cientifico de avicultura. Zaragoza, Spain, October $29^{\text {th }}$ November $2^{\text {nd }}, 2009$.

Quarles, C.L., and Kling, H.F. (1974). Evaluation of Ammonia and Infectious Bronchitis Vaccination Stress on Broiler Performance and Carcass Quality. Poultry Science, 53, 1592-1596.

Reindl, D.T., Beckman, W.A., \& Duffie, J.A. (1990). Diffuse Fraction Correlations. Solar Energy, 45 (1), 1-7. https://doi.org/10.1016/0038-092X(90)90060-P.

Resolución conjunta de los Ministerios de Industria, Energía y Turismo, y Ministerio de Fomento (2014). Factores de emisión de $\mathrm{CO}_{2}$ y coeficientes de paso a energía primaria de diferentes fuentes de energía final consumidas en el sector de edificios en España.

Ritz, C.W., Fairchild, B.D., \& Lacy, M.P., (2004). Implications of ammonia production and emissions from commercial poultry facilities: A review. Journal of Applied Poultry Research, 13, 684-692. 
Thornton, P.K. (2010). Livestock production: recent trends, future prospects. Philosophical Transactions of the Royal Society B (Biological Sciences), 365, 2853-2867.

Valentine, H. (1964). A study of the effect of different ventilation rates on the ammonia concentrations in the atmosphere of broiler houses. British Poultry Science, 5, 149-159.

Verspecht, A., Vanhonacker, F., Verbeke, W., Zoons, J., \& Van Huylenbroeck, G. (2011). Economic impact of decreasing stocking densities in broiler production in Belgium. Poultry Science, 90, 1844-1851.

Verstegen, M.W.A., Tamminga, S., \& Greers, R., (1994). The effect of gaseous pollutants on animals. In I.Ap. Dewi, R.F.E. Axford, I. Fayez M. Marai, \& H. Omed (Eds.), Pollution in livestock production systems (pp. 71-79). Oxon: CAB International.

Wathes, C.M., \& Charles, D.R. (1994). Livestock Housing, 1. Wallingford: CAB International.

Wathes, C.M., Jones, J.B., Kristensen, H.H., Jones, E.K.M., \& Webster, A.J.F. (2002). Aversion of pigs and domestic fowl to atmospheric ammonia. Transactions of the ASAE, 45, 1605-1610.

Weaver, W.D., \& Meijerhof, R. (1991). The effect of different levels of relative-humidity and air movement on litter conditions, ammonia levels, growth, and carcass quality for broiler-chickens. Poultry Science, 70, 746-755.

Yi, B., Chen, L., Sa, R., Zhong, R., Xing, H. \& Zhang, H. (2016). Transcriptome profile analysis of breast muscle tissues from high or low levels of atmospheric ammonia exposed broilers (gallus gallus). PloS one, 11(9), p.e0162631.

Zhang, Y., and Barber, E.M. (1995). An Evaluation of Heating and Ventilation Control Strategies for Livestock Buildings. Journal of Agricultural Engineering Research, 60, 217-225. 


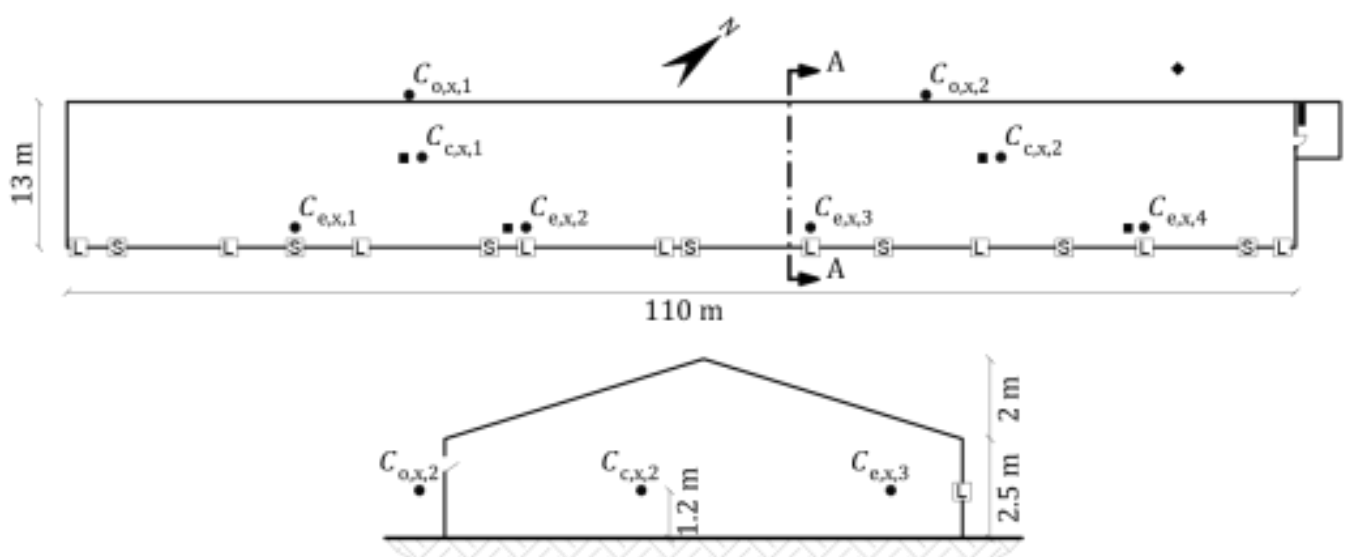

Section A-A

\section{Legend}

739

740

741

742
L. Large fan

s Small fan
- Outdoor air temperature and relative humidity sensor

- Indoor air temperature and relative humidity sensor
- Gas concentration $\left(C_{\mathrm{x}}\right)$ sensor

I Automatic climate control system

Fig. 1. Position of the sensors inside the broiler house. The figure shows also the main geometrical dimensions of the analysed house. Plan and cross section view (not at the same scale).

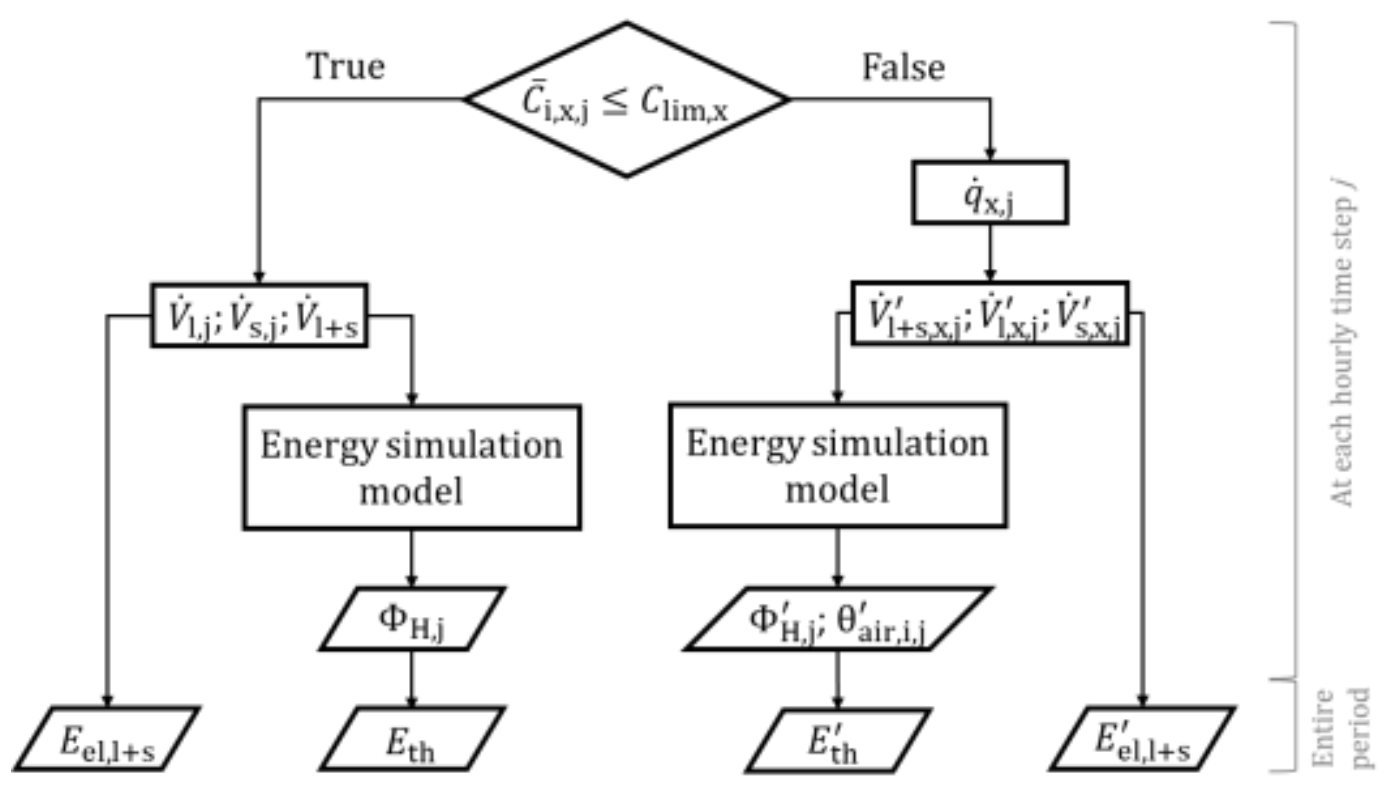

Fig. 2. Flow chart of the calculation process. 
a
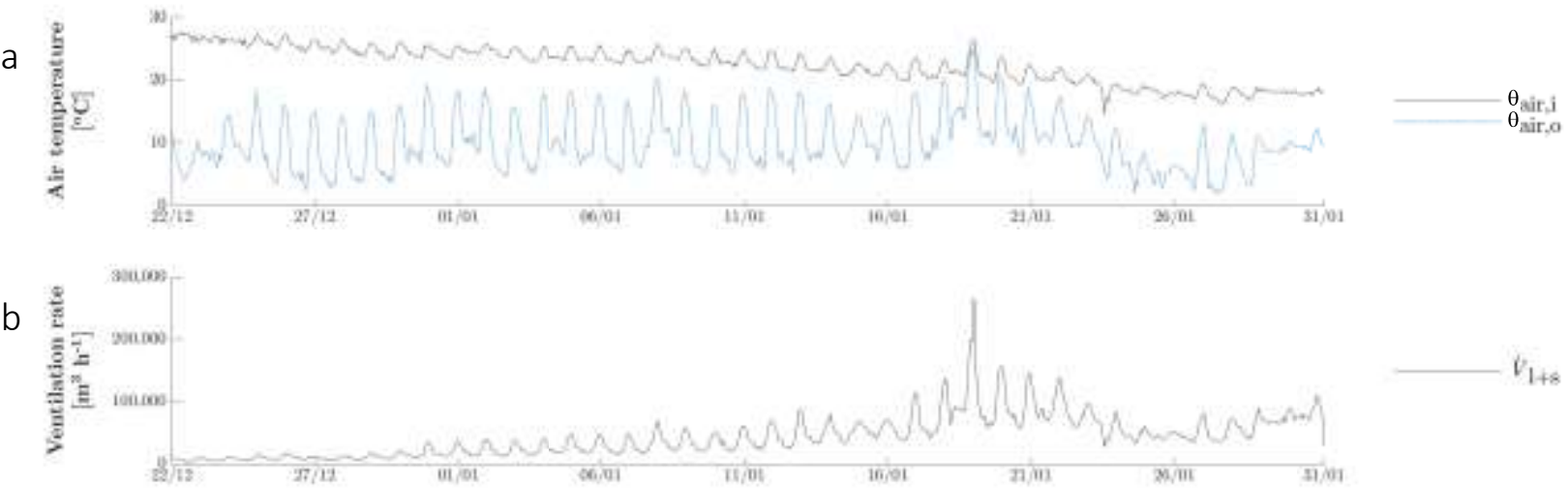

c
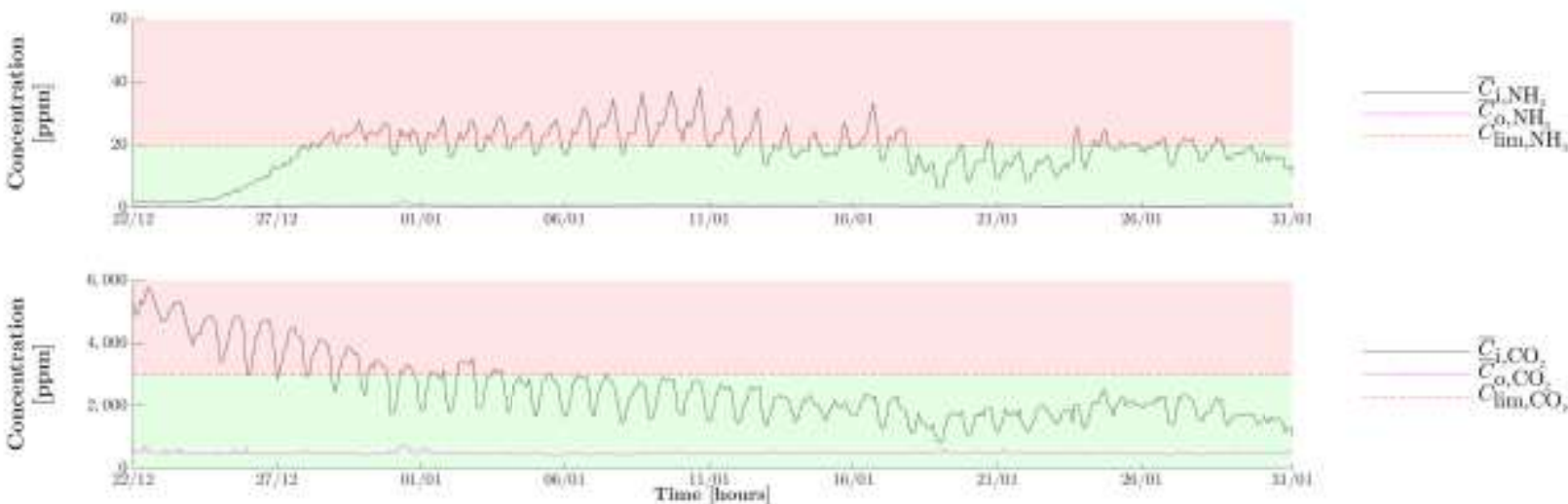

Fig. 3. a) monitored indoor $\theta_{\text {air, } i}$ and outdoor $\theta_{\text {air,o }}$ air temperatures;

b) actual total ventilation flow rate $\dot{V}_{1+s}$;
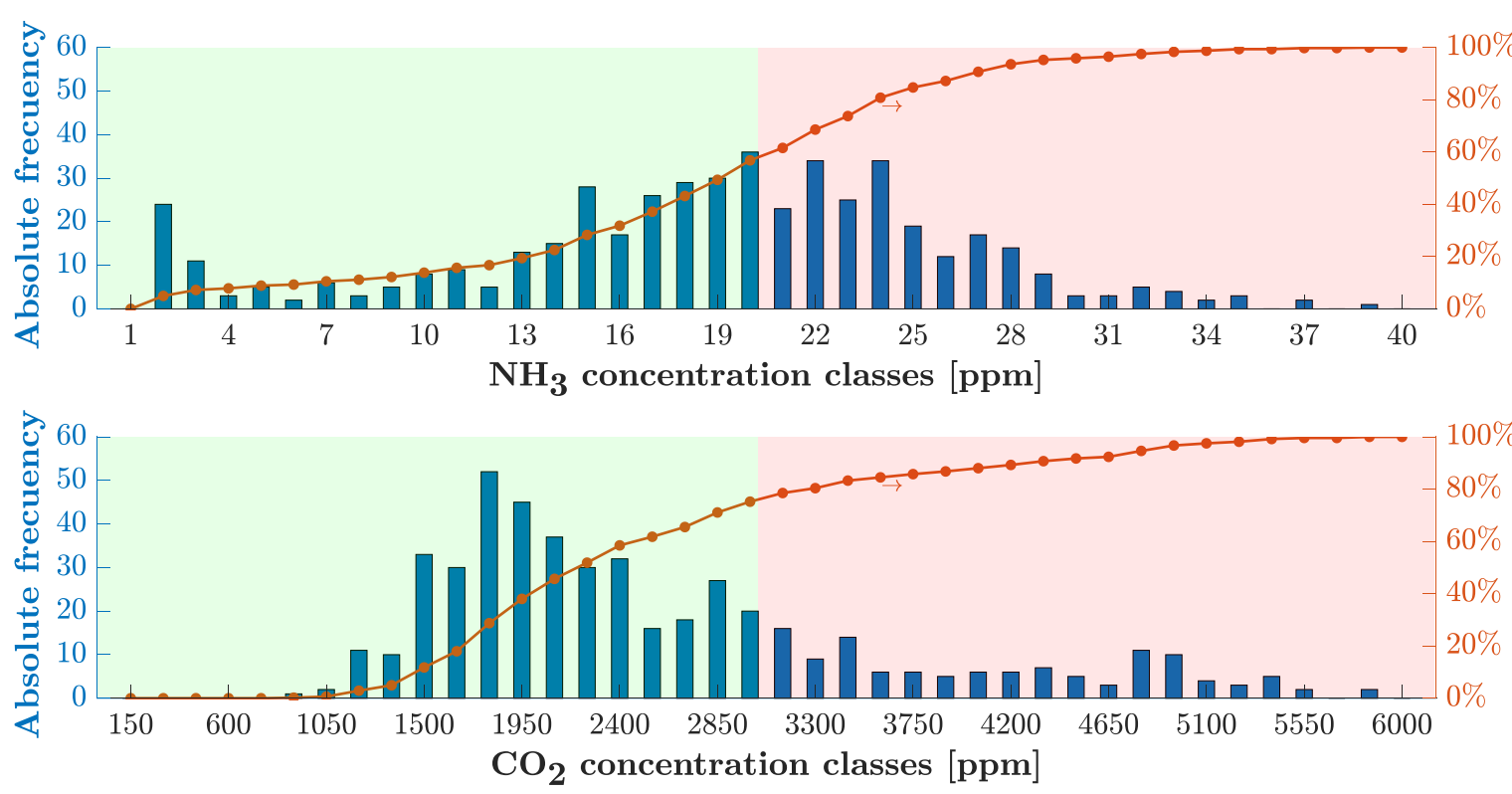

Fig. 4. Absolute and cumulative frequencies of:

b) monitored indoor average $\mathrm{CO}_{2}$ concentration $\left(\bar{C}_{\mathrm{i}, \mathrm{CO}_{2}}\right)$

(arrows indicate the reference axis). 


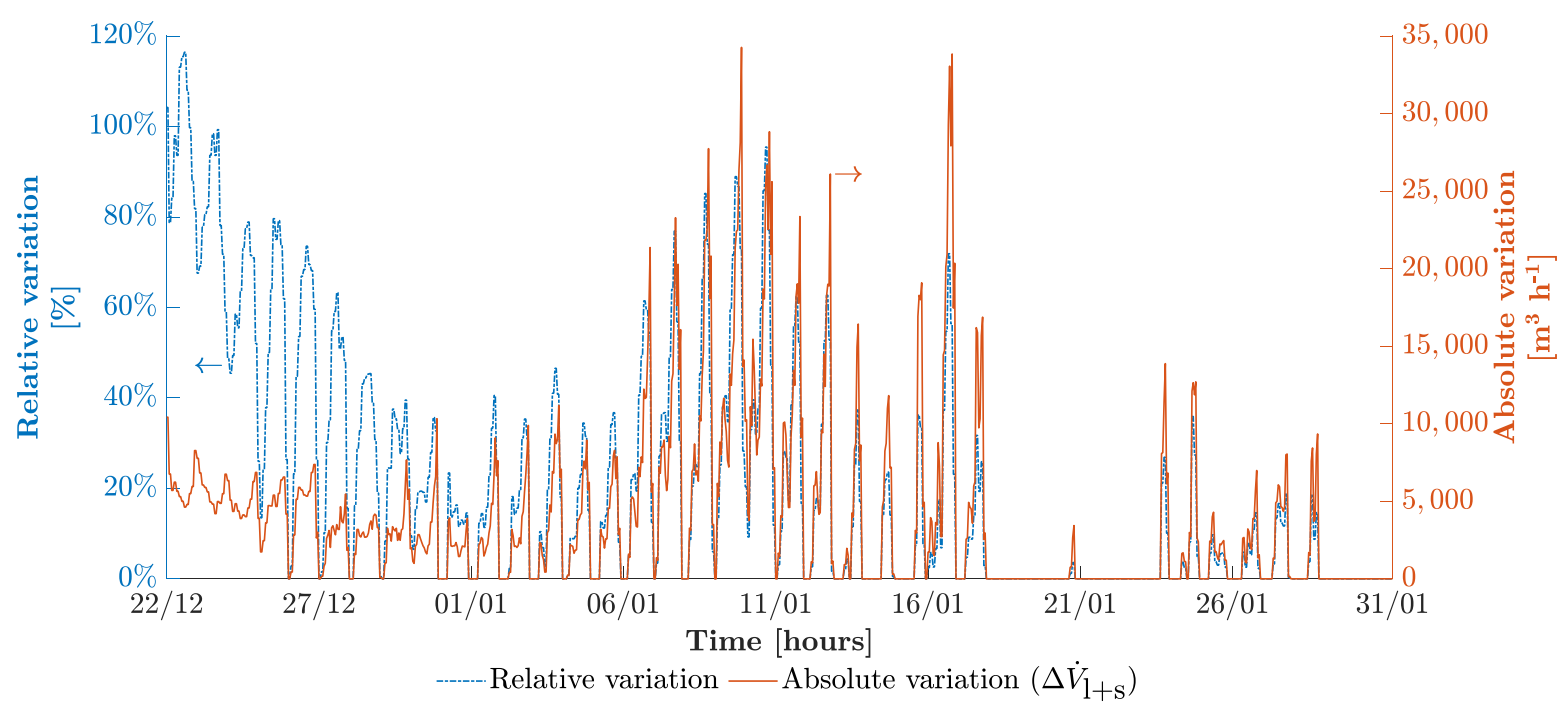

758

759

760

761

Fig. 5. Relative and absolute ventilation variation $\left(\Delta \dot{V}_{1+s}^{\prime}\right)$ between increased $\left(\dot{V}_{1+s}^{\prime}\right)$ and actual $\left(\dot{V}_{1+s}\right)$ ventilation flow rates (arrows indicate the reference axis).

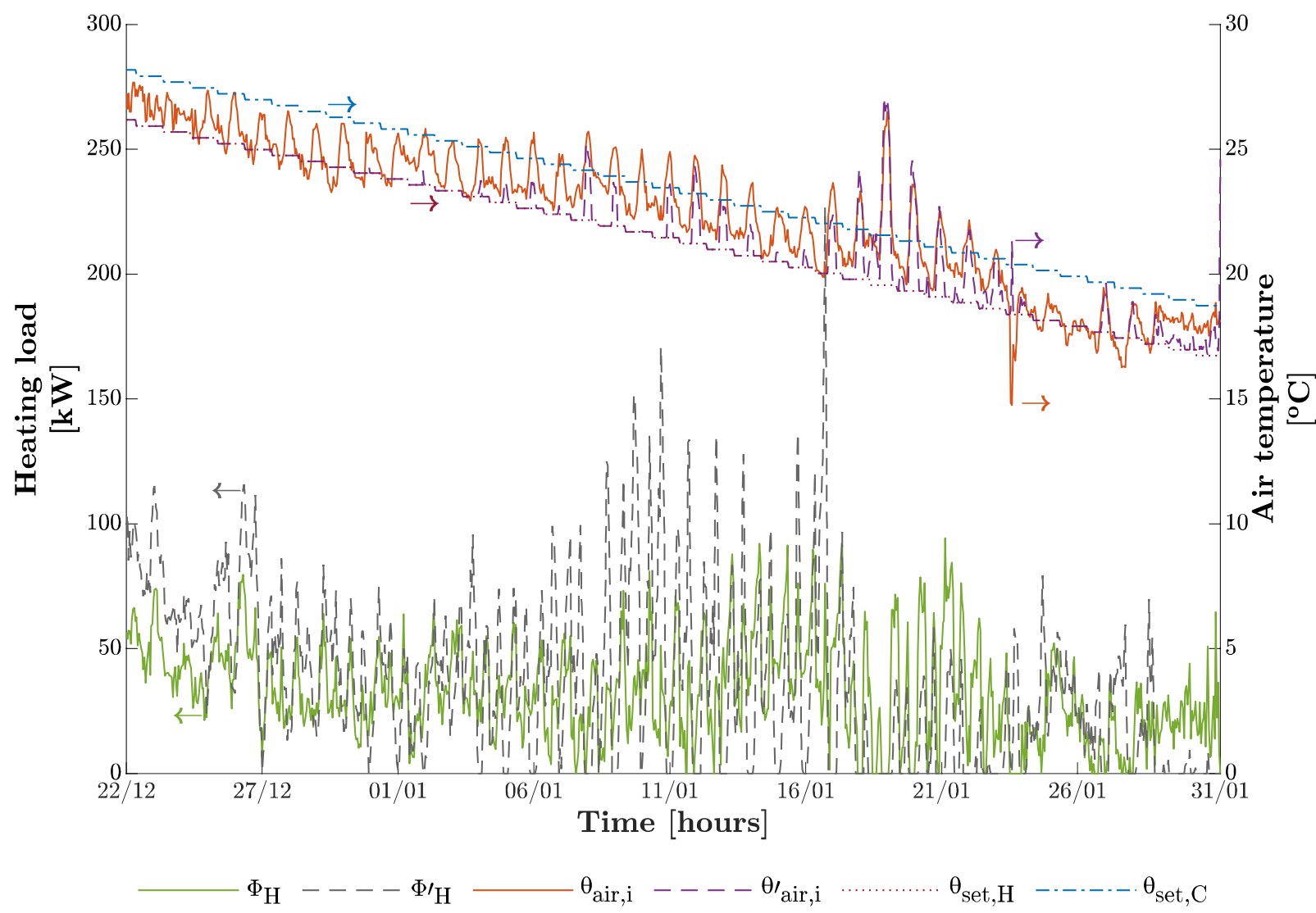

Fig. 6. Trend of indoor air temperature $\left(\theta_{\mathrm{air}, \mathrm{i}}\right)$, indoor air temperature considering increased ventilation $\left(\theta_{\mathrm{air}, \mathrm{i}}^{\prime}\right)$, heating $\left(\theta_{\mathrm{set}, \mathrm{H}}\right)$ and cooling $\left(\theta_{\mathrm{set}, \mathrm{C}}\right)$ set point temperatures. On the secondary axis, heating load $\left(\Phi_{\mathrm{H}}\right)$ and theoretical heating load $\left(\Phi_{\mathrm{H}}^{\prime}\right)$ are shown (arrows indicate the reference axis). 


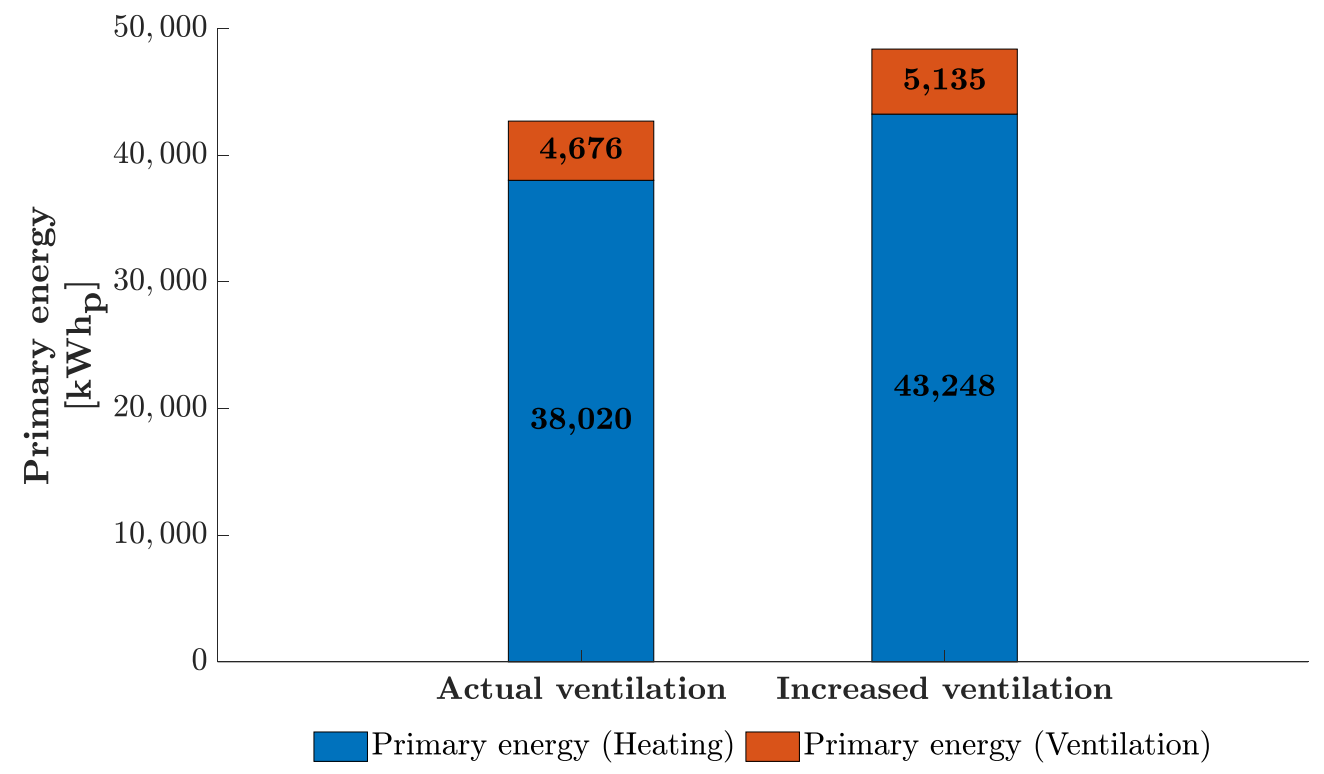

Fig. 7. Comparison between the total primary energy consumption (and the shares due to heating and ventilation) considering the actual and the increased ventilation flow rate. 